\title{
A Transaction Cost Economizing Approach to Regulation: Understanding the NIMBY Problem and Improving Regulatory Responses
}

\author{
Barak D. Richman ${ }^{\dagger}$ \\ Christopher Boerner $^{\dagger \dagger}$
}

This paper develops a transaction cost economic model for regulation and applies the model to environmental siting regulations designed to overcome NIMBY ("Not In My Back Yard") political opposition. Negotiations between developers and resistant local communities to site waste facilities, such as landfills or solid waste incinerators, can be characterized as a contracting problem. A rudimentary application of the Coase theorem suggests that developers should be able to compensate communities adequately for hosting a waste facility, but rarely do such negotiations find success. Transaction costs associated with the requisite negotiations, communication, and implementation of the projects preclude efficient bargaining, and thus NIMBY opposition halts the siting of socially necessary and beneficial facilities. Viewing NIMBY disputes as a contracting problem within the world of positive transaction costs therefore reveals the dynamics that foil negotiations between developers and communities. Such a perspective also identifies the role that the theory of the firm can play in understanding how siting regulations overcome those transaction costs and how regulatory regimes can be optimally designed for siting alternative facilities.

\footnotetext{
$\dagger$ Assistant Professor of Law, Duke University School of Law. J.D., Harvard Law School; M.A. Economics, University of California, Berkeley; A.B. Brown University.

$\dagger \dagger$ Associate Director of Oncology, Genentech, Inc. Ph.D., University of California, Berkeley; B.A., Washington University. The authors thank the participants at the BA298 Workshop at the Haas School of Business, the faculty workshop at Duke Law School, and the Environmental Law Workshop at the American Law and Economics Association annual meetings in May 2004, where the authors received valuable feedback. Thanks also go to Chris Baird, Stuart Benjamin, William Fischel, Steven Shavell, and Oliver Williamson for very helpful comments, and to Joy Hanson for superior research assistance. The authors acknowledge financial support from a Sasakawa Foundation grant to the University of California, Berkeley, the John M. Olin Center for Law, Economics, and Business at Harvard Law School, and the Duke University School of Law.
} 


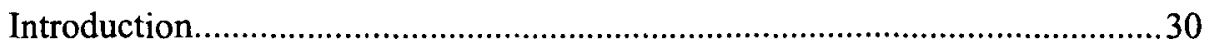

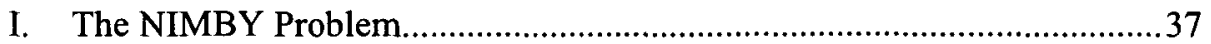

A. NIMBY as a Political Economic Problem …….....................................37

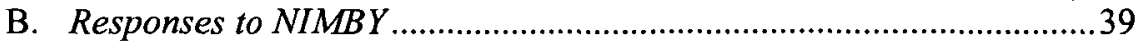

II. NIMBY Scholarship and Proposed Solutions ........................................42

A. Normative Approaches......................................................................42

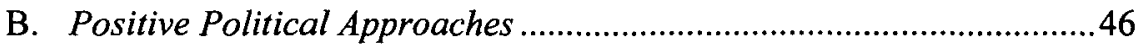

C. Transaction Cost Approaches ............................................................48

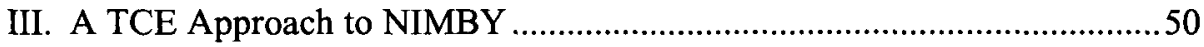

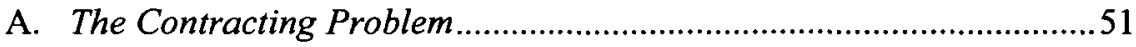

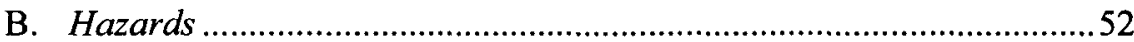

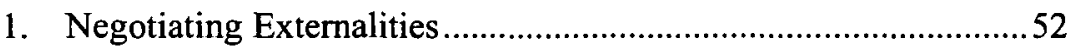

2. Measurement Problems …….......................................................5 53

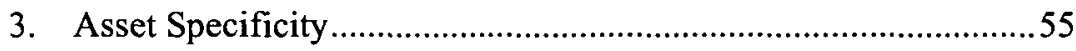

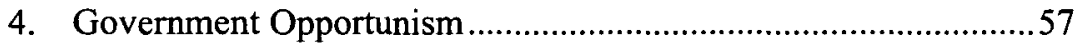

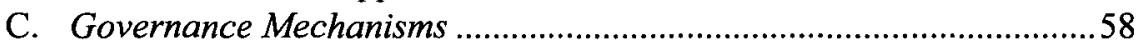

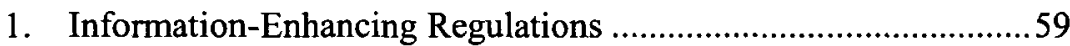

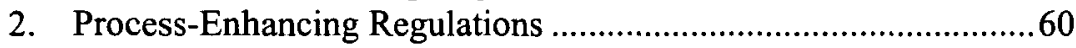

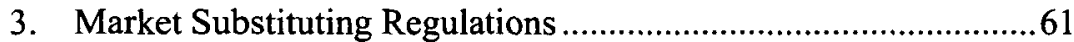

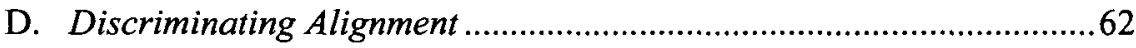

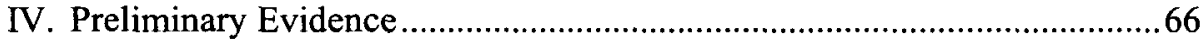

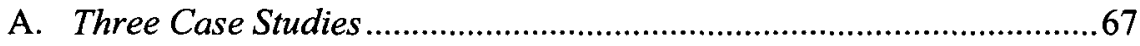

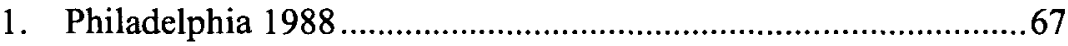

2. Dane County, Wisconsin, 1992 ..................................................... 70

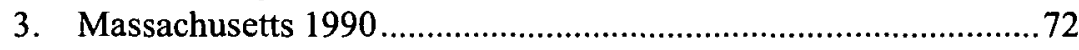

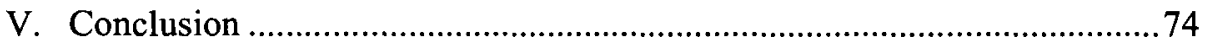

Introduction

A leading economist recently observed, "the theory of the firm has become a big business [and] one of the most fertile fields in the profession.", Theories of the firm certainly have come a long way. Ronald Coase gave birth to the field when in 1937 he observed that firms and markets "are alternative methods of co-ordinating production" and then posed the seminal make-or-buy paradigm: "The question which arises is whether it is possible to study the forces which determine the size of the firm. Why does the entrepreneur not organise one less transaction or one more?"2

1 Robert Gibbons, Four Formal(izable) Theories of the Firm 1 (MIT Dep't of Econ., Working Paper No. 04-34, 2004), available at http://ssm.com/abstract=596864.

2 R. H. Coase, The Nature of the Firm, 4 ECONOMICA 386, 388, 393-94 (1937). 
The theory of the firm has since branched out dramatically. While early scholarship first responded directly to Coase's make-or-buy question and developed formal theories to understand the size and parameters of firms, ${ }^{3}$ recent scholarship has extended make-or-buy theories to explore innovative research questions that do not involve the parameters of the firm. Such ventures have included examining the privatization of government functions, ${ }^{4}$ the organization of government agencies to attract private investment, ${ }^{5}$ and the organization of legislatures and political bodies to facilitate political agreements and compromises. ${ }^{6}$ Consequently, the theory of the firm has begun to explain far more than just the firm.

This Article moves that venture onward by employing the theory of the firm, specifically transaction cost economics, ${ }^{7}$ to understand the NIMBY ("Not In My Back Yard") problem, one of the most important and most vexing policy

3 Early leaders in the theory of the firm developed transaction cost economics. See OLIVER E. WILLIAMSON, MARKETS AND HIERARCHIES: ANALYSIS AND ANTITRUST IMPLICATIONS (1975); Benjamin Klein et al., Vertical Integration, Appropriable Rents, and the Competitive Contracting Process, 21 J.L. \& ECON. 297 (1978); Oliver E. Williamson, The Vertical Integration of Production: Market Failure Considerations, 61 AM. ECON. REV. (PAPERS \& PROC.) 112 (1971); Oliver E. Williamson, Transaction-Cost Economics: The Governance of Contractual Relations, 22 J.L. \& ECON. 233 (1979). A property rights theory of the firm then developed in the 1980s, see Sanford J. Grossman \& Oliver D. Hart, The Costs of and Benefits of Ownership: A Theory of Vertical and Lateral Integration, 94 J. POL. ECON. 691 (1986); Oliver Hart \& John Moore, Property Rights and the Nature of the Firm, 98 J. POL. ECON. 1119 (1990). And new theories of the firm continue to emerge, see, e.g., Raghuram G. Rajan \& Luigi Zingales, The Firm as a Dedicated Hierarchy: $A$ Theory of the Origins and Growth of Firms, 116 Q.J. ECON. 805 (2001) (articulating a theory of economic organization resting on dedicated hierarchies).

4 See, e.g., Oliver Hart et al., The Proper Scope of Government: Theory and an Application to Prisons, 112 Q.J. ECON. 1127 (1997) (using a property rights theory of the firm, with an emphasis on incomplete contract theory and residual control rights, to evaluate the privatization of government services); J. Bradford Jensen \& Geoffrey S. Rothwell, Transaction Costs, Regulation, and Subcontracting at Nuclear Power Plants, 36 J. ECON. BEHAV. \& ORG. 369 (1998) (using transaction cost economics to explain government privatization). See generally Andrei Shleifer, State Versus Private Ownership, 12 J. ECON. PERSP. 133 (1998).

5 See, e.g., Witold J. Henisz \& Bennet A. Zelner, The Institutional Environment for Telecommunications Investment, $10 \mathrm{~J}$. ECON. \& MGMT. STRATEGY 123 (2001) (relating public utility investments to political institutional design); Brian Levy \& Pablo T. Spiller, The Institutional Foundations of Regulatory Commitment: A Comparative Analysis of Telecommunications Regulation, 10 J.L. ECON. \& ORG. 201 (1994) (describing features of public institutions that attract private investment); Pablo Spiller \& Ingo Vogelsang, The Institutional Foundations of Regulatory Commitment in the UK: The Case of Telecommunications, 153 J. INSTITUTIONAL \& THEORETICAL ECON. 607 (1997) (suggesting that a prerequisite for private investment is a government's ability to credibly commit not to pursue arbitrary administrative actions).

6 See, e.g., Philip Jones \& John Hudson, The Role of Political Parties: An Analysis Based on Transaction Costs, 94 PUB. CHOICE 175, 181-88 (1998) (describing political parties as solutions to political market failures); Terry M. Moe, The Politics of Structural Choice: Toward a Theory of Public Bureaucracy, in ORGANIZATION THEORY: FROM CHESTER BARNARD TO THE PRESENT AND BEYOND 116 (Oliver E. Williamson ed., 1990) (describing the institutional attributes of alternative policy instruments); Barry R. Weingast \& William J. Marshall, The Industrial Organization of Congress; or, Why Legislatures, Like Firms, Are Not Organized as Markets, 96 J. POL. ECON. 132 (1988) (explaining that legislative institutions support political exchange by enabling actors to commit credibly).

7 For a comprehensive overview of transaction cost economics, including both the early applications to the parameters of the firm and the broader subsequent applications, see OLIVER E. Williamson, THE MECHANISMS OF GOVERNANCE (1996). 
challenges in the United States. ${ }^{8}$ The NIMBY syndrome, which arises with any effort to site locally undesirable but socially beneficial facilities, has stymied policy makers, local land use planners, and developers for generations. Because projects such as homeless shelters, prisons, airports, and waste disposal sites typically impose concentrated and localized costs while creating widely dispersed benefits, these facilities have often provoked intense resistance from local residents. Though the NIMBY problem has proven to be particularly intractable in the United States and Canada, it is a conflict endemic to all democracies-and to any system of government that permits localities to express and exert political opposition. ${ }^{9}$

Since the mid-1970s, however, the NIMBY problem in the United States has become more than a common nuisance, as certain facilities thought to be essential have become nearly impossible to site due to organized and persistent public opposition. ${ }^{10}$ Some noteworthy illustrations include the growing inability to site hazardous waste disposal facilities in the United States, the all but abandoning of nuclear power by U.S. utility companies, and the Department of Energy's persistent difficulties in selecting a permanent site for high-level radioactive waste. ${ }^{1}$ For solid and hazardous waste facilities, the siting problem has become so acute that some scholars have suggested that the "NIMBY" syndrome is perhaps better characterized as "BANANA"-_"Build Absolutely Nothing Anywhere Near Anything."

In an effort to counteract the growing success of local opposition and likewise to facilitate the building of locally undesirable but socially beneficial

8 See Kent E. Portney, Siting Hazardous Waste Treatment Facilities 10 (1991) ("Public opposition to facility siting has now reached the point where it has been given status as a fullscale public malady - the NIMBY, or Not-in-my-backyard, Syndrome.").

9 See Don Munton, Introduction: The NIMBY Phenomenon and Approaches to Facility Siting, in HAZARDOUS WASTE SITING AND DEMOCRATIC ChOICE 1, 9-10 (Don Munton ed., 1996).

10 See BARRY G. RABE, BEYOND NIMBY: HAZARDOUS WASTE SITING IN CANADA AND THE UNITED STATES 28 (1994) ("The dominant approaches to hazardous waste facility siting in Canada and the United States have given communities and individuals little reason to do anything other than attempt to block facilities once they have been proposed.").

11 Linda Cohen et al., The Politics of Nuclear Power in Japan and the United States, in StRUCTURE AND POLICY IN JAPAN AND IN THE UNITED STATES 177 (Peter Cowhey \& Matthew D. McCubbins eds., 1995); Joseph DiMento \& LeRoy Graymer, Introduction: LULU, Governance, and Regionalism: The Themes of the Volume, in CONFRONTING REGIONAL CHALLENGES: APPROACHES TO LULUs, Growth, AND OTHER Vexing Governance Problems 1 (Joseph DiMento \& LeRoy Graymer eds., 1991).

12 See Michael O'Hare ET Al., Facility Siting and Public OPposition (1983); DiMento \& Graymer, supra note 11 ; see also RABE, supra note 10 , at 1 ("No nation spends as much money per capita, generates as much political anguish, or accomplishes less in implementing its hazardous waste policies than does the United States."). "BANANA" is a term purported to have originated during the intense NIMBY disputes of the early 1990s, see, e.g., The Word Spy, BANANA,

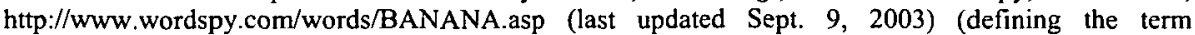
"BANANA"), but is currently used to portray a general policy impasse, see, e.g., PETER HALL \& ULRICH PFEIFFER, URBAN FUTURE 21: A GLOBAL AGENDA FOR TWENTY-FIRST CENTURY CITIES 297 (2000) (describing BANANA as an "urban paralysis"). 
facilities, states across the country have enacted numerous siting regulations. ${ }^{13}$ The specific nature of these reforms varies widely, ranging from relatively simple efforts to improve information exchange between developers and prospective host communities to more interventionist measures that give state officials the power to assume control over the siting of controversial facilities. However, many states have shunned facilitative measures in favor of more forceful interventions that steamroll local opposition and endow a developer with the forceful backing of a state power. ${ }^{14}$ These states have in place siting procedures that overcome NIMBY problems by removing siting processes from the political arena altogether. ${ }^{15}$

Most academic observers have been largely sympathetic to policymakers who seek forceful measures to counteract NIMBY opposition, ${ }^{16}$ and academic debate over the efficacy of these regulations has focused primarily on the wisdom of where NIMBY facilities are ultimately sited. ${ }^{17}$ This predominant view states that NIMBY opposition, albeit understandable, is simply in conflict with the larger public interest and thus should not deter the siting of a facility. ${ }^{18}$ A second cadre of academics has advocated a regulatory process that encourages community participation and the negotiation of compensation schemes. ${ }^{19}$ These scholars believe that the NIMBY challenge can be overcome, and community opposition can be pacified by finding the right price to pay nearby residents. Though both of these approaches have appeal, neither has achieved an admirable record of success. ${ }^{20}$ This failure is, in part, because few

13 See generally William B. Johnson, Annotation, Validity, Construction, and Application of State Hazardous Waste Regulations, 86 A.L.R. 4th 401 (1991) (discussing regulations "to the extent that they are reflected in ... reported cases").

14 See PORTNEY, supra note 8, at 8-10 (noting that several states have instituted either "preemptive" regulations, whereby a state agency can override local opposition, or "local input" regulations, which like preemptive regulations can override local opposition, but under which siting decisions are guided by statewide boards that include local officials).

15 Id.

16 See Orlando E. Delogu et al., Some Model Amendments to Maine (and Other States') Land Use Control Legislation, 56 ME. L. REV. 323, 345-46 (2004).

17 See, e.g., Patrick O'Hara, The N.I.M.B.Y. Syndrome Meets the Preemption Doctrine: Federal Preemption of State and Local Restrictions on the Siting of Hazardous Waste Disposal Facilities, 53 LA. L. REV. 229, 231-32 (1992).

18 See, e.g., Daniel Mazmanian \& David Morrell, The "NIMBY" Syndrome: Facility Siting and the Failure of Democratic Discourse, in ENVIRONMENTAL POLICY IN THE 1990's: TOWARD A NEW AGENDA 125, 125 -26 (Norman J. Vig \& Michael E. Kraft eds., 1990); Patricia Suter, The Siting System: Theory and Reality, 1 ALB. L. ENVTL. OUTLOOK 24, 24 (1995).

19 See infra notes 57-59, 69-76.

20 See Christopher J. Duerksen, Environmental Regulation of INDUSTRIal Plant SITING: HOW TO MAKE IT WORK BETTER 79-81 (1983) (noting that heavy-handed regulatory strategies are unlikely to site industrial facilities successfully and were more likely to backfire); WILLIAM T. Gormley, Taming the Bureaucracy: Muscles, Prayers, and Other Strategies 12, 16-17, 24 29 (1989) (observing that "muscular" regulatory measures have become increasingly popular but have delivered disappointing results); DAN M. KAHAN, THE LOGIC OF RECIPROCITY: A THEORY OF COLLECTIVE ACTION AND LAW (forthcoming 2006) (manuscript ch. 4, at 3, on file with authors) ("The idea that NIMBY can be overcome by offering host communities material compensation has proven extremely popular with both commentators and policymakers. But after two decades of experimentation, this strategy has produced only meager results."). 
researchers have attempted to understand the underlying logic of government regulation with respect to the NIMBY problem: What is the nature of the problem that prompts the necessity of siting regulations, how do regulations address the core features of the NIMBY problem, and what factors (if any) constitute an efficient regulatory response for a given NIMBY facility? We argue that pursuing such a foundational examination of regulatory solutions to the NIMBY problem will not only lead to a better understanding of the problem's sources and solutions, but will also lead to better regulatory policy.

Specifically, we argue that successful land use policies require policymakers to employ certain regulatory devices to match the specific challenges presented by individual facilities. To be sure, siting regulations must confront NIMBY opposition directly. If left alone in an uncorrected political market, NIMBY opposition will succeed in blocking the implementation of a socially desirable project; thus, political entities must control the political process and limit public participation. ${ }^{21}$ Accordingly, under certain circumstances, forceful regulatory responses that squelch NIMBY opposition are necessary and, as such, superior to participatory schemes. Under different circumstances, however, they generate policy outcomes that are decidedly less preferable to a hybrid of democratic participation and regulatory oversight.

The theory of the firm and transaction cost economics offer useful templates for understanding when incorporating public participation is useful and how it can be utilized effectively. The standard transaction cost model weighs the benefits of market pressures against the security of vertical integration, and it argues that transactions in need of some, but not complete, security should be governed within a market-hierarchy hybrid. ${ }^{22}$ This paper relates the market-firm balance to a similar balance between participatory democracy and forceful regulatory procedures, and it argues that regulations should turn to negotiated compensation schemes for some but not all NIMBY projects. Piggybacking on the extensive theory of the firm literature offers policymakers a detailed model for how to tailor regulations to specific NIMBY projects.

Part I begins with an overview of the NIMBY scenario, including the political and economic problems that NIMBY disputes present and typical regulatory responses to those problems. We observe that many states grant developers the authoritative powers and political muscle to neglect community opposition and squelch NIMBY resistance, and perhaps an equal number of

21 Just as the firm arises to correct for market failures, such as contractual holdups, contract incompleteness, and bilateral monopolies, regulation and other political instruments arise to correct for failures in the political market. The NIMBY challenge represents a failure of this second type because parties in a NIMBY problem routinely fail to reach compromise in the political arena. See WILLIAMSON, supra note 7, at ch. 8; see also the related literature on political market failures, supra note 6 . For an illustration of how NIMBY opposition leads to a political market failure, see Part IV, infra.

22 See WILLLAMSON, supra note 7, at 101-05. Market-hierarchy hybrids include long-term contracts, relational contracts, and cross-ownership. 
states employ participatory mechanisms to facilitate negotiations. But all states have developed their NIMBY regulations as a one-size-fits-all solution, and none has pursued a hybrid strategy that appreciates that NIMBY problems vary according to the facility to be sited and thus demand different regulatory solutions. Part II reviews the current NIMBY literature, which is divided sharply between those sympathetic to authoritarian regulatory responses and those advocating participatory strategies. The section then introduces the recent transaction cost analyses of government regulation, which is one instance in which the theory of the firm extends into new terrain. This latest transaction cost literature serves as an opening to the comprehensive analysis offered here.

In Part III we introduce our basic model for regulating the siting of waste facilities, such as landfills, solid waste incinerators, and hazardous waste treatment, storage, and disposal facilities. ${ }^{23}$ The basic premises underlying this model are threefold. First, the NIMBY issue can be formulated as a contracting problem in which a developer and a prospective host community negotiate over the terms and conditions under which a facility will be allowed to operate. Second, such transactions between developers and communities introduce certain contractual obstacles, or hazards, that preclude efficient bargaining. And third, this contracting problem can be understood through the lens of transaction cost economics, which states that hierarchical mechanisms of governance (e.g., contracts, firms, government controls, etc.) can support transactions burdened by hazards. ${ }^{24}$

Part IV then develops a comprehensive regulatory approach to siting NIMBY facilities, which posits that certain regulatory mechanisms can efficiently minimize transaction costs for siting certain categories of waste facilities. The central argument is fashioned after transaction cost economics' "discriminating alignment hypothesis": ${ }^{25}$ Alternative regulatory regimes can be matched with the siting of particular waste facilities so as to minimize transaction costs. In other words, while regulation may often be necessary to support siting a NIMBY project, reliance on a single regulatory process for siting all facilities is unwise. Instead, regulations should be tailored to the particular features of individual projects. This paper develops a taxonomy of regulatory strategies, identifies the characteristics of particular waste facilities that are important in NIMBY disputes, and proposes a methodology that optimally matches types of siting regulations with the targeted waste facilities.

In articulating this theory of regulation, this Article moves beyond the current literature by offering a comprehensive and generalizable model for

23 Waste and energy facilities were chosen for two reasons: First, these facilities have been among the most intensely opposed land uses; and second, this notoriety has led to a large body of literature upon which this paper could build.

24 See WilliaMSON, supra note 7 at 65-74.

$25 I d$. at 105-06. The discriminating alignment hypothesis, stated completely, is that transactions (which differ in their attributes) are aligned in a discriminating way with governance structures (which differ in their costs and competencies) so as to minimize transaction costs. 
regulatory policy. Whereas previous efforts focus on a specific policy question and formulate bifurcated policy options-such as whether a government should use public employees or private contractors for a specific objective, ${ }^{26}$ or whether a government should organize utility regulation under executive or parliamentary control ${ }^{27}$ - this Article charts a model of regulatory policy that offers recommendations for assorted public use demands. It thus provides a template from which policymakers can design a menu of effective regulatory policies. It also further illustrates the flexibility of Coase's original insightthat the reciprocal competencies of market forces and vertical integration can lead to valuable insights into the efficacy of alternative public policies.

Part IV then presents a preliminary empirical test of these hypotheses with selected case studies. Though these studies do not rigorously test the model, they indicate that viewing regulation as a mode of governance can provide valuable insights. Moreover, they are selected to illustrate a cross-section of scenarios-efforts to site different types of waste facilities and efforts to site facilities under different regulatory regimes. Together, the case studies impart three lessons. First, in the absence of a supportive regulatory regime, NIMBY opposition will succeed in impeding the siting of noxious facilities. Second, a regulatory regime that incorporates political participation from local political interest groups can, for some projects, successfully site NIMBY facilities and, importantly, can do so while accommodating local concerns. Such a regulatory process - one that both sites a socially desirable facility and wins the support of local communities-leads to land use outcomes that are superior to those that follow from an authoritarian regulatory process. And third, however desirable it may be to incorporate local political participation into siting a NIMBY facility, and however useful input from local communities may be, such a participatory regulatory process will simply fail to site some noxious but essential facilities.

Last, Part V remarks that the transaction cost template developed here can inform regulatory policies that reach beyond NIMBY disputes. Just as the NIMBY challenge can be modeled as a contracting problem, in which the regulatory process facilitates an agreement between two or more parties, other regulatory disputes can be similarly modeled. Since much of modern administrative law places government agencies in the position to facilitate disputes between different interest groups, ${ }^{28}$ our transaction cost model offers lessons for rulemaking procedures designed to solicit comment and forge consensus-oriented policies. In short, the template offered herein applies to policy challenges beyond the siting of noxious facilities and to political disputes beyond the NIMBY problem.

28 See, e.g., Alan B. Morrison, The Administrative Procedure Act: A Living and Responsive Law, 72 VA. L. REV. 253, 253-58 (1986). 


\section{The NIMBY Problem}

\section{A. NIMBY as a Political Economic Problem}

A NIMBY is defined as a socially desirable land use that broadly distributes benefits, yet is difficult or impossible to implement because of local opposition. While most often associated with polluting and waste facilities, NIMBY problems afflict a broad range of land uses, including airports, prisons, sports stadiums, power plants, halfway houses, and low-income housing projects. $^{29}$

Two important characteristics make each of these facilities a potential NIMBY problem. The first is that the project, if implemented, will generate an overall increase to social surplus. ${ }^{30}$ We define NIMBY problems as projects that are difficult to site only because of inequalities in distribution. Consequently, a NIMBY project generates additional surplus such that efficient transfer payments could, in theory, distribute gains in a manner that will entice all actors to support it. ${ }^{31}$ All NIMBY projects are potentially Pareto improving.

Second, the nature of the costs and benefits associated with these facilities virtually assures local opposition. Although the benefits of NIMBY projects, such as airports, prisons, and low-income housing, are typically dispersed among a relatively large population, the costs and risks of these projects are normally concentrated on a small group of residents in the host community. ${ }^{32}$ To residents who live near these facilities, the costs are almost always greater than the benefits, and they are usually better off if the project is either located elsewhere or not completed at all.

Even though NIMBY projects benefit more actors than they harm, and even though they generate an overall gain in social surplus, the nature of democratic institutions makes it extremely difficult for them to win political support. ${ }^{33}$ Consequently, they often succumb to a political process that yields to concentrated costs over diffuse benefits. ${ }^{34}$ Citizens residing near proposed sites for NIMBY facilities can both experience nuisances associated with the facilities (e.g., noise from airports) and can also fear suffering from such

29 For brief discussion of such NIMBY projects, see Michael B. Gerrard, The Victims of NIMBY, 21 FORDHAM URB. L.J. 495 (1994).

30 One important qualification must be noted. Any of these facilities can be planned inefficiently-i.e., can be constructed and sited in such a manner that they generate a decline in total surplus. A project's qualification as a NIMBY problem depends not just on the nature of the facility itself but also on contributing circumstances.

31 This follows the Coase Theorem, made famous in Ronald Coase's seminal article, see Ronald H. Coase, The Problem of Social Cost, 3 J.L. \& ECON. 1 (1960).

32 See RABE, supra note 10, at 1-2.

33 See PORTNEY, supra note 8, at 65-67.

34 Mancur Olson, THE Logic Of Collective ACtion: Public Goods and the TheORY OF GROUPS (1965). 
nuisances. ${ }^{35}$ Exposure, both actual and anticipated, to such concentrated costs provides strong incentives to organize, attend local hearings, ${ }^{36}$ lobby politicians and, if necessary, file legal challenges. ${ }^{37}$ In contrast, the benefits associated with these facilities are both broadly distributed (e.g., the benefits of an airport are spread to all travelers) and, compared to the local costs, diffusely allocated (the utility of enjoying expanded travel options is far outweighed by the disutility of constantly hearing airplanes overhead; it also is insufficient to induce an individual to volunteer in the political process and fight on behalf of an airport project). Consequently, few individuals aside from a project's developer have an incentive to advocate that a particular site under consideration is the best location for a project. ${ }^{38}$ Even the developer's attempts to argue that the overall gains outweigh the overall costs are often dismissed by opponents as self-serving. Consequently, widespread public support for locally undesirable land uses is generally lacking and is overcome by local opposition. This opposition is frequently sufficient to defeat most locally undesirable facilities, including those that provide net social benefits. ${ }^{39}$

These two conditions-overall efficiency and proneness to stifling political opposition-are particularly evident in the siting of solid and hazardous waste facilities. Economies of scale resulting from the large fixed costs associated with most waste facilities typically make it efficient to have one large facility servicing the waste needs of an entire region. ${ }^{40}$ However, the actual and perceived costs to neighbors associated with these facilities increase with facility size, so larger (and more efficient) facilities often elicit stronger public opposition than would smaller projects. Large regional facilities also encounter local hostility since residents perceive that they are bearing the costs of disposing of "other people's" waste. ${ }^{41}$ Furthermore, unlike projects such as airports and various industrial activities that can spark additional investment, solid and hazardous waste facilities normally provide few compensating

35 Michael O'Hare \& Debra Sanderson, Facility Siting and Compensation: Lessons from the Massachusetts Experience, 12 J. POL'Y ANALYSIS MGMT. 364 (1993).

36 GREgORY E. MCAVOY, CONTROLLING TEChNOCRACY: CitIZEN RATIONALITY AND THE NIMBY SYNDROME 124-25 (1999).

37 See Johnson, supra note 13, at 609-14; cf. GeORge W. Pring \& Penelope Canan, SLAPPS: GETTING SUED FOR SPEAKING OUT 2-3, 106-07 (1996) (describing the phenomenon of the government filing suits against citizens, strategic lawsuits against public participation).

38 Lawrence S. Bacow \& James R. Milkey, Overcoming Local Opposition to Hazardous Waste Facilities: The Massachusetts Approach, 6 HARV. ENVTL. L. REV. 265, 268-69 (1982).

39 O'HARE ET AL., supra note 12.

40 Howard Kunreuther et al., A Compensation Mechanism for Siting Noxious Facilities: Theory and Experimental Design, 14 J. ENVTL. ECON. \& MGMT. 371 (1987).

41 Larger facilities also distort traditional, common-law approaches to solving land-use disputes. As the magnitude of a nuisance increases, the number of affected persons increases. With multiple parties, common-law approaches to solving nuisance disputes become less efficient. The transaction costs associated with negotiating agreements increases geometrically as the number of people involved in the process increases. See JOHN O'LOONEY, ECONOMIC DEVELOPMENT AND ENVIRONMENTAL CONTROL: BALANCING BUSINESS AND COMMUNITY IN AN AGE OF NIMBYS AND LULUS (1995). 
benefits to their host communities. Most facilities, for instance, provide relatively few new jobs and only modest tax revenues. ${ }^{42}$ With few concentrated benefits for local residents, it is difficult for a waste facility developer to rally host community support. ${ }^{43}$

Chances for public support for siting waste facilities have been further injured by recent political developments. The industry's past failures to use environmentally sound waste disposal practices and the public fallout associated with many of these failures (e.g., Love Canal, ${ }^{44}$ Times Beach, the Santa Barbara oil fires, etc.) have severely damaged facility developers' credibility in the public eye. ${ }^{45}$ Moreover, a large, vocal, and well-funded environmental movement has heightened public anxiety about the dangers posed by waste facilities and has become an important force in challenging new developments. ${ }^{46}$ As a result, waste facilities are often perceived to pose greater risks to public health and safety than other locally undesirable facilities and are consequently especially prone to NIMBY political problems. ${ }^{47}$

Combined, these features present solid and hazardous waste facilities as a good vehicle to understand the NIMBY problem. While cost-effective development of such facilities encourages developers to build large facilities in one locale that service many other communities, the costs of siting large projects are shared unequally and create political dynamics that make attracting the requisite public support extremely difficult. The challenge this NIMBY problem presents policy makers is to create a political process that will site socially necessary facilities in a manner both responsive to the market demands of municipal solid waste and attentive to the preferences of adversely affected citizens.

\section{B. Responses to NIMBY}

A variety of public and private policies have emerged to respond to this political challenge. Traditionally, developers sited facilities using what has been termed the "DAD" paradigm: Decide, Announce, and Defend. ${ }^{48}$

42 Bacow \& Milkey, supra note 38; Frank Popper, LULUs and Their Blockage: The Nature of the Problem, the Outline of the Solutions, in CONFRONTING REGIONAL CHALLENGES: APPROACHES TO LULUS, GROWTH, AND OTHER VEXING GOVERNANCE PROBLEMS, supra note 11, at 13.

43 See KAHAN, supra note 20 , at 1 ("'S]ince each community would be better off were another to host that facility, all the communities resist.") (emphasis added).

44 Charles A. Wentz, HaZardous Waste Management 306-12 (1989).

45 See Thomas Lambert \& Christopher Boemer, Environmental Inequity: Economic Causes, Economic Solutions, 14 YALE J. ON REG. 195, 196 (1997) (noting that civil rights activists have recently joined forces with environmental groups to oppose construction of many solid and hazardous waste facilities on environmental justice grounds).

46 O'LOONEY, supra note 41; Bacow \& Milkey, supra note 38; Herbert Inhaber, Of LULUs, NIMBYs, and NIMTOOs, PUB. INT., Spring 1992, at 52, 63.

47 MCAVOY, supra note 36 , at 94-97.

48 See RABE, supra note 10 , at 28 ("Whether advanced by private or public entities, siting proposals are characteristically made with no prior consultation with targeted communities."). 
Developers decided the best location for their facility, took out options on the land, announced to political leaders of the community their intention to site, and then defended their decisions from local opposition groups. ${ }^{49}$ Under this strategy, developers competed against local opposition in an open political arena without the support of a regulatory siting process.

In the face of growing NIMBY opposition, however, the "DAD" strategy became increasingly unsuccessful, and developers were forced to pursue alternative tactics. Two new paradigms emerged. The first was obtaining regulatory protection from the state that could preempt local politics and override NIMBY opposition. Under this approach, a state agency is instructed to determine whether additional waste facilities are needed, consult with developers to determine where the facilities should be located, and then use strong-arm tactics to impose the decisions on resisting communities. Sometimes state agencies are permitted to use eminent domain powers, but in all cases the state regulatory process foreclosed the traditional political or legal mechanisms that opponents to the proposed facility normally could employ to stop the project. Some states permit local officials and representatives of affected communities to serve on the supervising state agency, but this often amounted to no more than token representation. Consequently, waste facility developers had only to interact with state officials and could largely avoid their political opponents. Most states opted for this coercive regulatory scheme, and it remains the predominant regulatory process that guides the siting of noxious facilities. ${ }^{50}$

A second approach has been labeled a market-based or compensationbased strategy, whereby developers devise mechanisms to compensate locally affected communities for their proximity to a noxious facility. ${ }^{51}$ Initially, many developers voluntarily pursued negotiations with representatives of prospective host communities in the hope of eliminating the causes of local opposition. ${ }^{52}$ In theory, these compensation schemes should always find a price that communities would accept and developers would pay to site the facility. Negotiations typically devised creative compensation schemes, such as constructing community projects, building public parks, or promising jobs and job training. Some siting agreements commit the developer to undertake actions to mitigate a facility's adverse impacts, such as creating a buffer zone around the noxious facility or providing emergency response systems, and others include particular obligations that the community may assume regarding the sited project. ${ }^{53}$

49 Lambert \& Boerner, supra note 45 , at 222.

50 See PORTNEY, supra note 8, at 8-10, 49-52; RABE, supra note 10, at 44-56.

51 See O'HARE ET AL., supra note 12; RABE, supra note 10, at 33-44.

52 RABE, supra note 10, at 33-44; Interview with William Ruckelshaus, CEO, BrowningFerris Industries, in St. Louis, Mo. (Apr. 28, 1995).

53 Interview with Ruckelshaus, supra note 52. Other actions frequently included in siting agreements are the provision of necessary infrastructure, such as a transportation network or a sewer 
Negotiations between developers and concerned local parties open a remarkable potential for improving the process for siting facilities-not only will community members have a voice in nearby projects, but developers also will acquire valuable, constructive information about local concerns and unforeseen costs a project would impose. However, these private negotiation initiatives have met with only moderate success, motivating the promulgation of a second category of state siting regulations: regulations designed to facilitate, or gently require, negotiations between developers and local communities to devise compensation schemes. ${ }^{54}$ This generation of regulations was fashioned to assist these negotiations and to encourage similar negotiation for situations in which bargaining was otherwise difficult. Most of these regulations were directed toward improving the exchange of information between developers of waste facilities and key constituents within prospective host communities, altering the process by which developers and local community representatives negotiate, and allowing the state to intervene directly in the siting process.

The advantage that compensation and market schemes have over preemptive regimes is clear. Assuming both successfully site socially necessary facilities, market mechanisms induce affected parties to reveal private information, convey preferences, and devise creative solutions to the NIMBY problem. ${ }^{55}$ Since the social objective is not just to site necessary facilities but to do so efficiently (i.e., maximizing some approximation of social utility), any regime that elicits the preferences of affected communities and orchestrates a compensation scheme would be, by hypothesis, superior to the unilateral decision of a developer or regulator. A critical question, however, is whether these negotiation-based strategies do, in fact, site facilities reliably. They are viable solutions to NIMBY challenges only if they overcome NIMBY opposition.

In sum, three siting strategies have replaced the traditional unilateral approach: seeking preemptive regulatory authority, pursuing voluntary negotiations with host communities, and the intermediate strategy of developing regulations that facilitate and require negotiations. As the following Part describes, each of these regulatory strategies has its advocates and, as Part IV illustrates, each strategy has, at best, a mixed record. ${ }^{56}$

system, and pledges to use clean technologies. Compensation payments may also include direct cash payments to the community or financial guarantees to uphold land values. In return for these steps, the community often pledges to support the project and provide various support services. note 35 .

54 O'HARE ET AL., supra note 12; RABE, supra note 10, at 33-44; O'Hare \& Sanderson, supra

55 See Barak D. Richman, Mandating Negotiations To Resolve the NIMBY Problem: $A$ Creative Regulatory Response, 20 UCLA J. ENVTL. L. \& POL'Y 223, 233-36 (2002).

56 Some commentators are less generous, describing the existing regulatory strategies as genuine failures. See sources cited supra note 20 . 


\section{NIMBY Scholarship and Proposed Solutions}

The rise of certain regulations as a response to siting difficulties has attracted significant attention from academics. Three approaches stand out in the literature. The first, which is home to a majority of the relevant scholarship, takes a normative approach to the NIMBY challenge, whereby researchers advocate a regulatory recipe to resolve the NIMBY political impasse. The second, which is more removed from our purposes but nonetheless deserves attention, is chiefly predictive and uses economic models of the political process to generate positive predictions of regulatory outcomes. The third perspective is the transaction cost economics methodology, which explains how regulations can facilitate economic transactions either between two private parties or between private and public entities. Although we place our approach within the normative camp since we propose here a model for regulatory reform, our analysis assumes the same wide-angled lens that is employed in transaction cost models.

\section{A. Normative Approaches}

A fundamental dispute swirls in academic circles over whether siting regulations are a solution to the NIMBY impasse or part of the problem. The "property rights" school falls into the latter category and expresses genuine skepticism towards regulatory efforts to site noxious facilities. According to these scholars, the siting problem is one of ambiguously specified property rights.

Robert Cameron Mitchell and Richard T. Carson, for instance, argue that under current siting regulations neither the developer nor the community holds clear property rights. ${ }^{57}$ On the one hand, local communities use strict zoning and safety regulations to assert their right to be free of NIMBY projects, and on the other, state siting boards have typically countered these efforts by granting competing siting rights to developers. The competing layers of regulatory rights make property rights ambiguous and impede efficient negotiations for land uses. Mitchell and Carson suggest that states should officially recognize the de facto property rights assumed by local communities, and this would allow prospective developers to freely negotiate siting terms with these communities. ${ }^{58}$ This argument is akin to traditional law and economics scholarship that focuses on selecting a legal rule, usually assigning property rights or liability, in order to achieve optimal incentives. Most of these arguments presuppose that once property rights are specified, court adjudication is sufficient to identify when siting agreements have been violated,

57 Robert Cameron Mitchell \& Richard T. Carson, Property Rights, Protest, and the Siting of Hazardous Waste Facilities, 76 AM. ECON. REV. 285 (1986).

58 Id. 
assess the behavior of the responsible actors, assign liability, and, when required, compensate victims. ${ }^{59}$

The primary problem with the property rights school is that the recent waves of regulatory innovations have proven its inadequacy. The rise of the intractable NIMBY problems arose chiefly before developers and planners turned to regulatory policies to overcome local opposition. ${ }^{60}$ The emergence of the alternative regulatory solutions itself is evidence that securing property rights, without more, is inadequate to site noxious facilities. ${ }^{61}$

A more fundamental problem with the property rights approach is its failure to appreciate the complexities inherent in the NIMBY phenomenon. At its core, the property rights approach presumes that efficient bargaining, akin to the Coasean world of zero transaction costs, ${ }^{62}$ is possible and would occur were it not for inefficient regulatory interventions. Empirical evidence certainly suggests otherwise, as NIMBY negotiations are laden with emotional and coordination pitfalls that prevent efficient bargaining. ${ }^{63}$ But there is a more methodological difficulty with this approach. It is a critique that compares current siting regulations to a hypothetical ideal, rather than to feasible alternatives. ${ }^{64}$ It is easy to point out how siting regulations, or any government intervention, would generate inefficiencies in a perfectly efficient market with costless negotiations, if for no other reason than because they directly interfere with any "invisible hand" that a free market may offer. But such neoclassical assumptions do not consider the complex realities of negotiating certain transactions, and they overlook fundamental bargaining hazards that preclude laissez-faire efficiency. Explicit comparisons of existing siting regulations to hypothetical or untested ideals (to which few markets can aspire and against which no regulation can compete) are helpful neither in modeling the problem nor in suggesting its solution.

A closer examination of the property rights approach reveals some additional problems. Efficient bargaining rests on an accurate reflection of the affected community's preferences and its ability to organize and negotiate proficiently, but any community is home to competing views and contrasting preferences. Mitchell and Carson suggest establishing communal property

59 See Peter S. Menell, The Limitations of Legal Institutions for Addressing Environmental Risks, 5 J. ECON. PERSP. 93 (1991) (discussing the property rights approach to siting noxious facilities and its potential flaws in addressing environmental problems). See generally WILLIAM M. LANDES \& RICHARD A. POSNER, THE ECONOMIC STRUCTURE OF TORT LAW (1987); RICHARD A. POSNER, EConomic Analysis of LaW (4th ed. 1992); Steven Shavell, The Economic analysis of ACCIDENT LAW (1987).

60 See supra notes 13-15 and accompanying text.

61 See also infra Part IV, for additional evidence that siting noxious facilities requires regulatory supports.

62 See Coase, supra note 31.

63 See infra notes 73-77 and accompanying text.

64 This critique of economic orthodoxy is inherent in much of the transaction cost literature. See WILLIAMSON, supra note 7. 
rights to allow communities to accept or reject a proposed NIMBY project. ${ }^{65}$ Although their argument may have some theoretical appeal, translating theory into practice reveals the difficulty of establishing clearly defined and enforceable property rights when many actors are involved. One possibility is to use referenda for the approval of new developments. But these have been thwarted by individual community members representing minority views who routinely engage in various legal and extra-legal tactics to end-run the referendum process and stop an approved development. ${ }^{66}$ Another possibility, as some negotiation literature suggests, is to appoint neighborhood leaders to represent the interests and exercise the property rights of the host community. ${ }^{67}$ But this is equally vulnerable to opportunities for defection and noncooperation by smaller factions. Given the complexity of the political process-and the complexities inherent in a NIMBY dispute-a regulatory superstructure to organize interested parties and facilitate negotiations is a prerequisite to effective bargaining. Any disdain by the property rights camp for regulatory interventions is therefore hypocritical.

Another normative approach to solve NIMBY problems, the "mechanism design" strategy, is more supportive of regulatory solutions. Researchers in this camp have directed their efforts toward developing government regulations and designing alternative siting mechanisms that would maximize some composite of social utility. ${ }^{68}$ Several noteworthy examples fall into this camp, such as Howard Kunreuther's proposed sealed-bid auction mechanisms for siting noxious facilities, ${ }^{69}$ Herbert Inhaber's proposals to employ a reverse Dutch auction, ${ }^{70}$ and Michael O'Hare's ${ }^{71}$ and Lawrence Bacow's and James Milkey's ${ }^{72}$ research on the use of compensation schemes. While critical of current siting processes, researchers in this branch maintain that appropriate government programs can reduce or eliminate current siting difficulties.

65 Mitchell \& Carson, supra note 57.

66 There is a frequent and inescapable tension between referenda, which bestow decisionmaking responsibilities to citizens, and the legislative process, which confers authority to elected officials. Employing one political mechanism inherently weakens the other. See, e.g., Schwarzenegger's Risky End Run, CHRISTIAN SCI. MONITOR, March 3, 2005, at 8.

67 See LAWRENCE SuSSKIND \& PATRICK FIELD, DEALINg WITH AN ANGRY PUBlic 99-100 (1996); Alun Richards, Using Co-management To Build Community Support for Waste Facilities, in HAzARDOUs WASTE SITING AND Democratic ChOICE, supra note 9, at 321, 321-22, 331-37. See generally LAWRENCE SUSSKIND ET AL., NEGOTIATING ENVIRONMENTAL AGREEMENTS (2000).

68 The objective, of course, is not just to site socially desirable yet noxious facilities but to do so efficiently, which requires eliciting local preferences and likely involves compensating local communities. Thus, while preemptive regulation may successfully site facilities, it does not attempt to (and thus likely fails to) maximize social utility.

69 Paul R. Kleindorfer \& Howard Kunreuther, A Sealed-Bid Auction Mechanism for Siting Noxious Facilities, 76 AM. ECON. REV. 295 (1986); Kunreuther et al., supra note 40.

70 HERBERT INHABER, SLAYING THE NIMBY DRAGON passim (1998); see also Inhaber, supra note 46.

71 O'HARE ET AL., supra note 12; O'Hare \& Sanderson, supra note 35.

72 Bacow \& Milkey, supra note 38. 
A growing literature within the field of negotiation can also be placed in the mechanism design school. Resting on theories from an amalgam of fields, such as economics, psychology, and political science, this collection of research scrutinizes common bargaining strategies employed by developers and host communities. ${ }^{73}$ These works identify certain elements of the negotiation or mediation process that create gridlock, and they proceed to develop normative approaches to aid developers in negotiating with host communities. ${ }^{74}$ Many of these strategic recommendations include entering into a "consensual approach" that encourages participants to create a voluntary, ad hoc discussion forum to resolve disputes. ${ }^{75}$ Other works encourage employing public mediators who can formalize an alternative dispute resolution mechanism. ${ }^{76}$ Most of this literature presupposes that negotiation strategies can arrive at Pareto-improving resolutions when one is theoretically possible, ${ }^{77}$ and the challenge is to encourage parties to commit to a negotiation process and collectively explore value-creating options.

The primary problem with these mechanism design proposals is that they advance a one-size-fits-all solution for a host of diverse NIMBY challenges. Yet the problems associated with siting an airport are not the same as the problems associated with siting a nuclear power plant. Asymmetric information, complexity, and other contractual hazards are at the heart of many NIMBY disputes, but these hazards vary significantly according to the type of facility in question. Specifically, a negotiation-based regulatory strategy may work for one type of noxious facility but may fail to successfully site another. A land use policy that recognizes these differences will appreciate that a regulatory mechanism that deals effectively with one NIMBY dispute may be ill-suited to deal with others. This variation in siting facilities, and the subsequent variation in the performance of regulatory mechanisms, demands a flexible regulatory policy. ${ }^{78}$

One illustration of the shortcomings of a one-size-fits-all approach and its faith in negotiated solutions is Bacow and Milkey's efforts to institute incentive

73 See, e.g., PORTNEY, supra note 8, at 123-36.

74 See id. at 138-39 (introducing risk substitution as an alternative approach).

75 LAWRENCE SUSSKIND \& JEFFREY CRUIKSHANK, BREAKING THE IMPASSE: CONSENSUAL APPROACHES TO RESOLVING PUBLIC DISPUTES (1987); SUSSKIND ET AL., supra note 67.

76 Susan Carpenter, Dealing with Environmental and Other Complex Public Disputes, in COMMUNity MEDIATION: A HANDBOOK FOR PRACTITIONERS AND RESEARCHERS 313 (Karen Grover Duffy et al. eds., 1991).

77 One interesting exception is Dan Kahan's critique of compensation-based schemes to resolve NIMBY disputes because citizens do not simply weigh the costs of noxious facilities versus the benefits of compensation, but rather evaluate siting decisions on principles of reciprocity of fairness. See Dan Kahan, The Logic of Reciprocity: Trust, Collective Action, and Law, 102 MICH. L. REV. 71, 89 (2003) (arguing that "individuals can be made receptive to the siting of noxious facilities in their communities if they can be made to believe that society is committed to treating their interests with respect"); see also, KAHAN, supra note 20.

78 These mechanism design proposals also lack a nuanced understanding of negotiating NIMBY disputes-a defect that also plagues the property rights approaches. Many of these nuances, or contracting hazards, are detailed in Section III.B. 
and compensation schemes to replace traditional preemptive siting approaches. ${ }^{79}$ In part due to Bacow and Milkey's research and lobbying efforts, Massachusetts passed the Massachusetts Hazardous Waste Facility Siting Act of 1980, which requires hazardous waste facility developers to negotiate compensation packages with prospective host communities. ${ }^{80}$ Unfortunately, the purported improvements offered by these incentive approaches have not materialized. As Michael O'Hare and Debra Sanderson point out, Massachusetts has not seen any improvement in the siting process since the negotiation statute was enacted. ${ }^{81}$ Indeed, no new hazardous waste facilities have been sited since the statute was passed in 1980, despite a significant demand. ${ }^{82}$ Without discounting the contribution made by Bacow and Milkey's scholarship, it is clear in this instance that claims regarding the inadequacies of the traditional siting process are in need of qualification. ${ }^{83}$ Simply put, the compensation schemes are far from fatally flawed, but they have substantial limitations. Proponents of such schemes, including Bacow and Milkey, overlook the contracting hazards inherent in siting waste facilities, and the market-oriented incentive approach they advocate has apparently been inadequate in overcoming political opposition.

In short, much of the normative literature addressing the NIMBY challenge has been too quick to criticize preemptive regulations and perhaps too confident in compensation or negotiation strategies. If the objective is to site facilities while considering the welfare of affected communities, and perhaps devising compensation schemes for those communities, then preemptive strategies are open for cutting criticism. However, both the property rights and the mechanism design schools fail to recognize some of the difficulties in reaching agreements for siting noxious facilities and thus oversell their own approaches. A better approach is to evaluate these alternative regimes according to their reciprocal strengths and deficiencies, such that regulatory strategies balance efficiency motives with the realistic hazards of political opportunism.

\section{B. Positive Political Approaches}

A second approach to understanding the emergence of regulation in response to NIMBY disputes involves a positive perspective of the political process. According to this approach, political interest groups organize to

79 Bacow \& Milkey, supra note 38. See generally, SUSAN BROWER BOYLE, AN ANALYSIS OF Siting New HaZARdous WaSte MANAGEMENT FaCIIITIES THROUgh a COMPENSATION AND INCENTIVES APPROACH (1982) (proposing compensation schemes to site hazardous waste facilities and discussing four case studies).

80 Mass. Gen. Laws ANn. chs. 21C, $21 \mathrm{D}$ (West 2002); Mass. Gen. Laws ANN. ch. 40A (West 2004); MASS. GEN. LAWS ANN. ch. 111 (West 2003).

81 O'Hare \& Sanderson, supra note 35, at 364.

82 Id.

83 See PORTNEY, supra note 8, at 58. 
influence the development of regulatory rules, aiming to enact rules that would best meet their particularistic interests. Thus an understanding of a polity's interest groups, their competing preferences, their relative resources, and the polity's political process enables the prediction of political outcomes. This school has its roots in George Stigler's ${ }^{84}$ and Sam Peltzman's examinations of regulated industries, and it has burgeoned to study how numerous regulatory and political processes are shaped by institutional configurations and a political market for votes. ${ }^{85}$ Positive political theory would predict that siting regulation has emerged to meet the particularistic needs of developers and organized community interests (whether environmental groups, civil rights groups, or some organized combination thereof). It would further predict that the regulations would favor the organized groups that invest the greatest amount of resources in the political process, and conversely, positive theory has useful explanatory power to predict regulatory outcomes.

Even though our emphasis is chiefly normative, positive theories of regulation are specifically helpful to our enterprise because they help explain the current matrix of regulations, with all its shortcomings. Political powers can skew such regimes to be either excessively pro-developer or pro-community. Polities with powerful pro-development interest groups, for example, would yield regulatory regimes that are friendly to developers' needs and would give little opportunity for local opposition to deter or usefully inform a siting process. Such regulatory regimes would generate what we label "overregulation"- the use of authoritarian regulations that preempt market-based dialogue when more participatory and negotiation-based regulations would achieve better outcomes. Similarly, polities with anti-developer and proneighborhood alignments would create a political process that offers inadequate regulatory support, or "under-regulation," for NIMBY projects. Such regimes make NIMBY projects particularly vulnerable to attack from local opposition and thus fail to construct socially necessary facilities. ${ }^{86}$ Put differently, our analysis does not assume ex post efficiency - i.e., that the regulatory regimes we observe are, in any respect, socially optimal-and positive political theory explains how the political process creates the inefficient regulatory regimes that we propose to amend.

Another useful purpose for positive political theory in our analysis is that it heightens our sensitivity to the political environment in which siting regulations are enacted. Our focus on NIMBYs as a contracting problem

84 George J. Stigler, The Economic Theory of Regulation, 2 BELL J. ECON. 3 (1971).

85 Sam Peltzman, Toward a More General Theory of Regulation, 19 J.L. \& ECON. 211 (1976); see also Joseph P. Kalt \& Mark A. Zupan, Capture and Ideology in the Economic Theory of Politics, 74 AM. ECON. REv. 279 (1984); James M. Snyder, Jr., Campaign Contributions as Investments: The U.S. House of Representatives, 1980-1986, 98 J. POL. ECON. 1195 (1990). This is a very large school of literature, and we intend only to introduce it briefly here.

86 The case studies of Philadelphia and Massachusetts, infra Part IV, illustrate instances of inadequate regulatory support. 
between opposing parties-and our resulting attention to the microanalytic details of the resulting NIMBY dispute-requires an awareness of the surrounding political environment, the relative power of competing interest groups, and the relevant political processes. ${ }^{87} \mathrm{~A}$ siting process that considers the particular features of each particular NIMBY project must include a consideration of the political environment in which the siting process takes place. In other words, for the same reason a one-size-fits-all approach to siting different facilities is doomed to failure in any polity, a one-solution-for-all policy prescription for all polities is doomed to failure in siting any particular waste facility.

In sum, although our model measures the efficiency of all outcomes according to certain theoretical criteria, developed below, our analysis must take into account lessons from positive political theories. Accordingly, the transaction cost approach is not at cross-purposes with positive analysis but, instead, incorporates and is informed by it.

\section{Transaction Cost Approaches}

Transaction Cost Economics (TCE) offers an alternative approach to understanding NIMBY problems and their regulatory remedies. Although much of the research in TCE has focused on the firm-market boundary, the theory has broader applicability. ${ }^{88}$ TCE maintains that any problem that arises as or can be posed as a contracting problem can be examined in transaction cost economics terms. ${ }^{89}$ Thus, to the extent one can think of regulation as a response to a contracting problem, TCE analysis can be fruitful.

Works by Victor Goldberg and Oliver Williamson are credited for being the first to approach regulation as a response to transactions that were difficult to contract. ${ }^{90}$ Goldberg chastised critics of regulation (many of whom could now fall into the normative schools discussed above) for not appreciating the contractual complexity of private alternatives. ${ }^{91}$ Hazards inherent in the nature of commonly regulated activities make most private alternatives nonremediable, leading instead to "administered contracts" that often involve intervention from a public agency to provide long-term administrative supports. Williamson fleshes out these contracting difficulties in examining efforts to

87 See, e.g., Levy \& Spiller, supra note 5 (explaining, in a cross-national study, how differences in political and regulatory environments explain the varying success of private investment).

88 See, e.g., Howard Shelanski \& Peter Klein, Empirical Research in Transaction Cost Economics: A Review and Assessment, 11 J.L. ECON. \& ORG. 335 (1995); JEFFREY T. MACHER \& BARAK D. RICHMAN, TRANSACTION COST ECONOMICS: AN ASSESSMENT OF EMPIRICAL RESEARCH IN THE SOCIAL SCIENCES (Duke Law School Mimeo, 2005).

89 WilliaMSON, supra note 7.

90 Victor P. Goldberg, Regulation and Administered Contracts, 7 BELL J. ECON. 426 (1976); Oliver E. Williamson, Franchise Bidding for Natural Monopolies-In General and with Respect to CATV, 7 BELL J. ECON. 73 (1976).

91 Goldberg, supra note 90. 
provide cable television to the city of Oakland. ${ }^{92}$ The transactions involved in such a fixed-cost endeavor for a municipality were laden with contractual hazards motivated by both economic and political circumstances. Williamson concludes that the (comparatively) efficient mechanism to oversee such economic activity is administrative contracts that allow for public intervention and renegotiation.

Building on these specific case studies, a more general approach has developed in which the individual hazards within specific transactions are matched with appropriate governance mechanisms. In short, governance mechanisms-whether regulation or other institutions-arise to address and mitigate specific hazards. This literature has been joined by broader theoretical treatments by Avinash Dixit and more recent work by Williamson, both of whom explicitly characterize regulation as a governance mechanism. ${ }^{93}$ These efforts formulate the entire spectrum of public sector activity as an array of transactions, each with varied types and degrees of hazards. Regulation, along with other public institutions, arises as a transaction cost-minimizing response to govern certain political and economic activities.

This paper pursues the path set forth by the recent work of Dixit and Williamson by viewing regulation as akin to a hybrid mode of governance in the markets-and-hierarchies template of traditional transaction cost theory. ${ }^{94}$ In our formulation, different regulatory mechanisms can manifest in a diverse collection of public interventions in the private market, and consequently they can possess different governing attributes. Figure 1 below, adapted from Williamson's 1999 article, Public and Private Bureaucracies: A Transaction Cost Economics Perspective, ${ }^{95}$ illustrates how regulation as a hybrid form fits into traditional TCE analysis.

92 Williamson, supra note 90.

93 AVINash K. Dixit, The Making of Economic Policy: A TRansaction-Cost Politics PerspeCtIVE (1996); Oliver E. Williamson, Public and Private Bureaucracies: A Transaction Cost Economics Perspective, 15 J.L. ECON. \& ORG. 306 (1999).

94 Williamson, supra note 93.

95 Id. 


\section{Figure $1^{96}$}

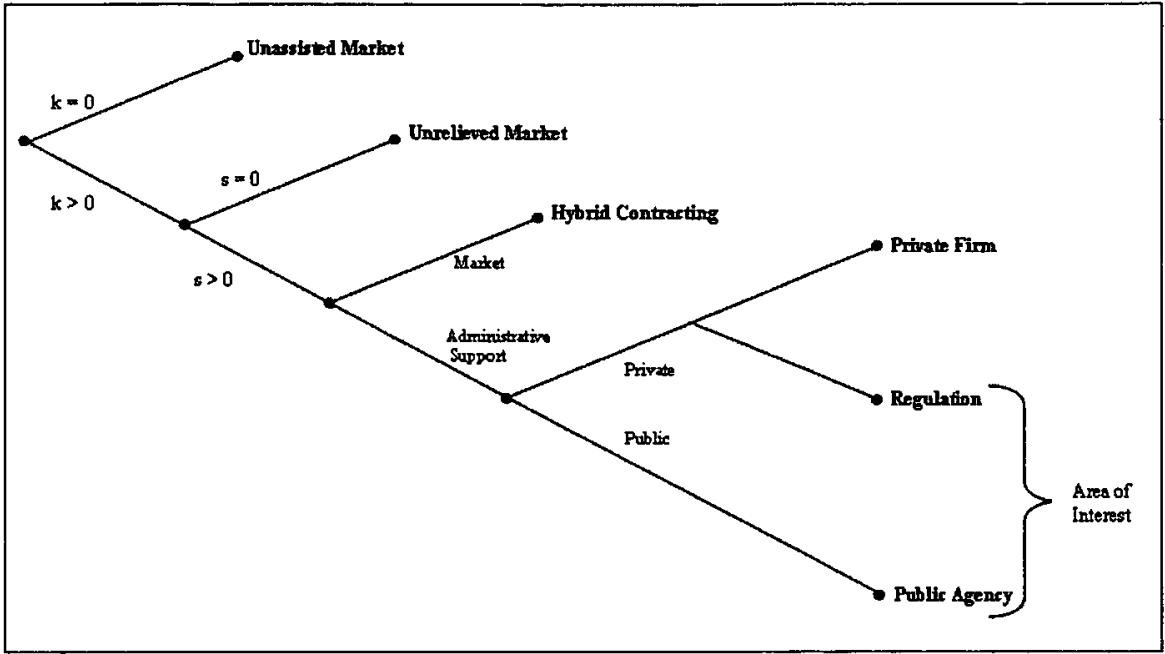

This paper focuses on the different administrative mechanisms that span from the regulation node, representing the regulation of a private firm, to the public agency, representing public ownership of the particular economic activity (we highlight this "Area of Interest" in Figure 1). Our framework illustrates the logic of government regulation with respect to the NIMBY problem. Siting noxious facilities is essentially a contracting issue in which a facility developer and local residents negotiate the terms and conditions under which a proposed facility will be located in a given community. However, various attributes associated with noxious facilities-specifically solid and hazardous waste facilities-jeopardize these negotiations. The analytical process of observing contracting hazards and identifying the corresponding governance mechanisms that offer useful solutions is the essential exercise in TCE. This process is applied below to siting waste facilities and their corresponding siting regulations.

\section{A TCE Approach to NIMBY}

Employing TCE analysis to understand siting regulations for solid and hazardous waste facilities involves a three-step process. The first is to articulate the exact nature and degree of the contractual hazards posed by such waste

96 Figure based on $i d$. at 337. In TCE heuristics, the letter $k$ denotes transactional hazards, and the letter $s$ denotes contractual safeguards. Figure 1 reflects all feasible values for $k$ and $s$, and TCE predicts a positive correlation between $k$ and $s$. Specifically, when $k=0$, transactions can occur unassisted in the spot market without safeguards, and when $k>0$, transactions will likely find their optimal governance structure where $s>0$. The conditions $k>0$ and $s=0$ reflect the "unrelieved market," in which transactions are unlikely to take place. 
facilities and how these hazards might prevent efficient facility siting. The second is to identify the regulatory governance mechanisms that have evolved to deal with these hazards and explain how these regulations can facilitate the siting of controversial waste facilities. The third is to formulate a hypothesis that explains how a proper alignment of regulatory mechanisms with specific siting transactions generates efficient returns. After formulating the siting process as a formal contracting problem, this Part proceeds through each of these steps.

\section{A. The Contracting Problem}

Formulated as a contracting problem, siting a waste facility requires an agreement between the developer and those others, mostly local residents, adversely affected. Without an agreement, local residents can sue the developer and claim damages or invade the political process and create gridlock. Conversely, an agreement between the developer and those affected can include provisions that will avoid imposing costs on residents or appropriately compensate those residents who do experience costs.

Waste facilities deemed to be NIMBY projects create additional social surplus, so, theoretically, transfer payments may be made to appropriately compensate residents for the costs imposed by the facility. In a world of efficient bargaining and zero transaction costs, this is accomplished in a straightforward manner: A developer announces a planned facility, local residents will demand compensation for the costs the facility will inflict, and the developer meets each resident's reservation utility through transfer payments. $^{97}$

Many developers now pursue this strategy through negotiation. ${ }^{98}$ Typically, negotiations for a siting agreement begin between a facility developer and representatives of the affected local municipalities, often represented by a citizens' committee. ${ }^{99}$ Beyond the terms and conditions under which a facility will be sited, virtually any subject is open for discussion. Among the items often arising in negotiations and included in final agreements are direct payments between developers and the affected municipalities, property value protection, disposal privileges, availability of local roads and utility services, operation guidelines, creation of standing oversight committees, and the provision of various community amenities, such as parks and playgrounds. ${ }^{100}$ Final agreements can also spell out dispute resolution

97 See Coase, supra note 31.

98 See O'HARE ET AL., supra note 12 (discussing case studies); SUSSKIND \& CRUIKSHANK, supra note 75 (proffering a suggested template to pursue a negotiation strategy); supra notes $52-53$ and accompanying text.

99 For example, the Massachusetts statute requires citizen participation through Local Assessment Committees (LACs). PORTNEY, supra note 8, at 57-58.

100 List compiled from a review of contracts filed with the Wisconsin Department of Natural Resources. 
procedures, such as appeal to state agencies or the use of binding arbitration. ${ }^{101}$ A successful siting process will typically (1) enable the contractual parties to engage in bargaining over the specific terms under which a facility will be allowed to operate; (2) provide mechanisms to facilitate adaptation to changing conditions over the life of the facility; and (3) establish a means by which parties can enforce agreements.

\section{B. Hazards}

In a world of complete certainty and zero transaction costs, the above conditions are easily met, and fully contingent and binding agreements can be reached. In such a world, all relevant parties are known in advance, all effects of the facility are known and specified ex ante, and contractual performance is transparent ex post.

But the real world is quite different, and Coase himself emphasized that thinking about a world without transaction costs is "without value except as steps on the way to the analysis of the real world of positive transaction costs." 102 Continuing down that analytical path requires recognizing that all contracts are unavoidably incomplete. Siting solid and hazardous waste facilities are transactions laden with uncertainty, impacted information, lack of trust, and other difficulties-or, to use TCE terminology, "contracting hazards"- that impede efficient bargaining. Faced with this incompleteness and the resulting transaction costs, efforts to guard against contractual hazards take on added importance. Four of these potential hazards warrant particular attention: negotiating externalities, measurement problems, asset specificity, and political opportunism.

\section{Negotiating Externalities}

Efficient bargaining requires a solid definition of property rights, ${ }^{103}$ but when a developer wants to negotiate with a community, it is not obvious who deserves standing, i.e., who can reasonably claim to be adversely affected by a facility at a specific site. Moreover, those whom the proposed facility genuinely will harm may have different interests and exhibit conflicting demands for compensation. Thus, one of the most important prerequisites to entering negotiations, and one of the first major hurdles facing a private developer in the siting process, is determining who represents the community in negotiations.

101 O'HARE ET AL., supra note 12, at 170-71; SUSSKIND \& CRUIKSHANK, supra note 75, at

102 Ronald H. Coase, The Coase Theorem and the Empty Core: A Comment, 24 J.L. \& ECON. 183,187 (1981). Coase continues, "We do not do well to devote ourselves to a detailed study of the world of zero transaction costs, like augurs divining the future by the minute inspection of the entrails of a goose." Id.

103 Coase, supra note 31. 
Individual parties within a community, however, have certain incentives not to enter into organized bargaining with the rest of the community. Any party who can claim legal standing and can file a lawsuit may be able to halt construction of a facility and force direct negotiations with the developer. Yet, if a developer is confronted with the prospect of negotiating individually with each affected party-under the threat from each that a lawsuit could suspend the project-then bargaining costs may become insurmountable. ${ }^{104}$ Furthermore, some environmentally motivated interest groups may have ulterior motives to stop the project altogether, so direct negotiations with them would inevitably prove to be fruitless. These dynamics could be considered "negotiating externalities" since individuals have greater incentives to negotiate individually, but individual negotiations may impose insurmountable obstacles to siting a facility that would actually increase overall welfare. Individual incentives alone, without the intervention of governance mechanisms to facilitate negotiations, would lead to Pareto-inferior outcomes. ${ }^{105}$ Consequently, these externalities impose serious contracting hazards to siting transactions.

\section{Measurement Problems}

A critical point of contention in siting negotiations is the impact the proposed facility will have on adjacent natural and human environments. Contracting around this issue requires that parties to the agreement (a) understand what effects are likely, (b) are aware of safeguards available to remedy these effects, and (c) can discern when these safeguards have failed. Measurement problems, however, can introduce transaction hazards and hinder bargaining from accomplishing these goals. ${ }^{106}$ Many measurement problems are traceable to a condition of impacted information: namely, when information is asymmetrically distributed between parties and can be equalized only at great cost. ${ }^{107}$ Information can be similarly impacted if it is costly to apprise an arbiter of the true information condition when a dispute arises among equally wellinformed parties.

In the context of solid and hazardous waste facilities, measurement problems arise from the inability to effectively relate contractual performance

104 This is akin to a legally-created anticommons, in which each member of an adversely affected neighborhood has the right to bring suit and thus the capacity to halt development. See Michael A. Heller, The Tragedy of the Anticommons: Property in Transition from Marx to Markets, 111 HARV. L. REV. 621 (1998).

105 This is true even factoring the environmental groups into the social-surplus equation. We recognize that certain environmental groups would enjoy more utility if no facility were built at all, but these preferences diverge from those belonging to the host community, who could be better off under transfer payments and a credible agreement. (1982).

106 Yoram Barzel, Measurement Cost and the Organization of Markets, 25 J.L. \& ECON. 27 
to outcomes. In the siting of waste facilities, the three conditions that would enable contracts to internalize the costs to local residents-parties' knowledge of a facility's future effects, available safeguards against those effects, and signs the safeguards have failed - are likely to be absent (in varying degrees) for two reasons. First, information is not symmetrically distributed. Developers have much better information about the likely social, economic, and environmental impacts of proposed facilities than do residents of prospective host communities. Public officials and community representatives involved in siting negotiations frequently complain that they lack sufficient information to make informed decisions. There is also a general suspicion that the information provided is selective at best and intentionally misleading at worst, meaning that information asymmetry is exacerbated by unaligned incentives to share information. ${ }^{108}$

Second, the complexity and uncertainty associated with waste facilities makes leveling the information playing field very costly and perhaps impossible. Understanding and evaluating the risks these facilities may pose to surrounding environments is a complicated process made more so by significant scientific disagreement. ${ }^{109}$ The general public is frequently unable to evaluate for itself the likely effects of a proposed facility or to make sense of the technical and often contradictory analyses of others. Even if one could achieve a scientific consensus regarding a given facility's potential effects, long latencies, uncertainty regarding causation, and the large number of potentially liable parties would make it difficult to definitively link the activities of a waste facility with a particular outcome.

One exacerbation of measurement problems that plagues NIMBYs is the significant risk aversion - and the inability to insure against risk-exhibited by individual homeowners affected by a NIMBY project. Even for projects that are expected to improve land values, or for projects that promise adequate compensation to adversely affected individuals, homeowners appropriately fear that a project may detrimentally affect the value of their homes (even after factoring in compensation), which for many families is their most valuable possession and which can constitute the vast majority of a family's nonretirement assets. As one economist put it, it is not the expected value of a project that worries such homeowners, but rather the risk posed by the significant variance in outcome. ${ }^{110}$ Since the risk of such a potentially devastating financial loss is uninsurable, residents are likely to mount significant opposition even in the face of reasonable assurances against adverse outcomes. This rational risk aversion is an important avenue through which

108 O'HARE ET AL., supra note 12, at 89-117; SUSSKIND \& FIELD, supra note 67 at 115-16; Bacow \& Milkey, supra note 38, at 265-69, 302-05.

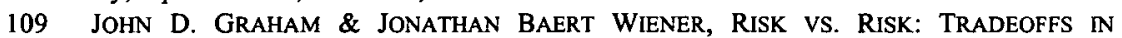
Protecting HEALTH AND THE ENVIRONMENT (1995).

110 See William A. Fischel, Why Are There NIMBYs?, 77 LAND ECON. 144, 144-45 (2001). 
measurement, communication, and information asymmetry problems impede a smooth siting process. ${ }^{11}$

For transactions that feature both impacted and asymmetric information, it is difficult to describe fully and accurately the responsibilities of each party in the contract ex ante and to assess whether these obligations have been fulfilled ex post. Consequently, parties to the contract have opportunities to engage in the strategic withholding of critical information or to engage in efforts to evade performance. A developer, for example, might withhold information about a project's adverse consequences or understate the probability of an adverse event in order to minimize compensation payments necessary to secure the support of a prospective host community. Likewise, host community residents might file false claims against a facility in order to extract compensation or to achieve desired changes in the facility's operations. ${ }^{112}$ Even if all parties dutifully fulfill their contractual obligations, the mere possibility that each party might act opportunistically gives negotiating partners reason to worry and to distrust the bargaining process. In sum, the very nature of information critical to siting waste facilities creates hazards that hinder parties from making credible agreements and thus deter efficient bargaining.

\section{Asset Specificity}

A third contracting hazard with important organizational implications in the siting process is asset specificity. This type of hazard arises because constructing waste facilities requires investments in assets that are nonredeployable, so developers will hesitate to begin a project before safeguards can protect their investment.

Three types of asset specificity arise in this context. The first is the traditional physical asset specificity common to the TCE literature. ${ }^{113}$ Investments in plant equipment for waste disposal may have few alternative uses, so local residents or other parties may identify opportunities to extract quasi-rents ${ }^{114}$ by threatening legal intervention or other hold-ups. Second, for several of these facilities, site specificity presents a key contractual hazard. Hazardous and solid waste facilities are often sited in a particular region in

111 For a more detailed examination of this argument, and the broader implications for local government, see WILLIAM A. FISCHEL, THE HOMEVOTER HYPOTHESIS (2001).

112 Aspects of environmental law make it easier for these superfluous suits to actually get to court. For a discussion of the consequences of section 107(a) of the Comprehensive Environmental Response, Compensation and Liability Act, under which liability for the release of a hazardous substance is based on strict liability and requires no element of causation, see THOMAS F.P. SULLIVAN, THE ENVIRONMENTAL LAW HANDBOOK 225 (13th ed. 1995).

113 Klein et al., supra note 3.

114 A quasi-rent is a short-term economic gain that one party obtains by charging more than the competitive price for a good. Hold-ups present opportunities for quasi-rents because the "held-up" party risks having its investments lose their value and thus is willing to pay a premium to make good use of those sunk investments. From the ex ante perspective, an investor would forgo making nonredeployable investments if she detects the possibility of being held-up. Id. at 298-302. 
order to serve nearby local waste producers. ${ }^{115}$ Once an investment in a facility is made, the developer is locked into a long-term commitment with particular customers, and a "cheek-by-jowl" relationship ensues, much like those created when coal-fired electric generation facilities are sited next to specific mines from which most of their coal will be extracted. ${ }^{116}$ In these cases, local interests can attempt to capitalize on the inability of these facilities to easily relocate. Protestors can move to block either the facility's operation or the flow of waste needed for the facility to remain profitable. The possibilities of having their investments held hostage are sufficient to drive developers to demand preemptive and credible assurances during the early stages of negotiation.

A third type of asset specificity-one that has not previously been mentioned in the TCE literature-could be described as legally induced asset specificity. This asset specificity, which applies only to certain hazardous and radioactive waste facilities, results from the peculiar nature of U.S. environmental law. Under section 107(a) of the Comprehensive Environmental Response, Compensation and Liability Act (CERCLA), for example, the current landowner is jointly and severally liable for environmental damages caused by facilities on the land. ${ }^{117}$ This liability is imposed regardless of the landowner's involvement in the handling of solid or hazardous substances on the site and regardless of when such substances were deposited at the facility. ${ }^{118}$ As a result, once the treatment and disposal of hazardous substances has begun at a site, the site's owner will have difficulty finding new buyers who are oblivious to the threat of liability, significantly reducing the value of the property's next best use. ${ }^{119}$ Unlike physical and site specificity, legally induced specificity is more a function of the political environment-the planned facility's location and legal backdrop-than of the nature of the facility itself. Consequently, the degree to which it affects siting projects depends more on the location and legal backdrop than on the nature of the facility.

Under each type of asset specificity, the scope of opportunism is expanded. Because their investments have discretely lower value in alternative applications, developers are effectively isolated from alternative trading opportunities, which open the door to the extraction of quasi-rents. When asset

11519 KIRK-OTHMER ENCYClopedia OF CHEMICAL TECHNOLOGY 175 (Jacqueline 1. Kroschwitz ed., 4th ed. 1996) (citing "proximity to market" among important factors in selecting a location for a waste facility).

116 See Paul L. Joskow, Contract Duration and Relationship-Specific Investments: Empirical Evidence from Coal Markets, in CASE STUDIES IN CONTRACTING AND ORGANIZATION 104 (Scott E. Masten ed., 1996); Paul Joskow, Vertical Integration and Long Term Contracts: The Case of Coal Burning Electric Generation Plants, 1 J.L. ECON. \& ORG. 33 (1985).

117 Comprehensive Environmental Response, Compensation, and Liability Act, 42 U.S.C. $\S \S$ 9601-9675 (2000).

118 SUlLIVAN, supra note 112, at 225.

119 See Barbara Ruben, Government Programs and Regulations Can Revitalize Abandoned Urban Brownfields, in GARBAGE AND WASTE: CURRENT CONTROVERSIES 167, 169-70 (Charles P. Cozic ed., 1997), for a discussion of the difficulties CERCLA liability poses for transferring abandoned sites of hazardous waste facilities. 
specificity is combined with the hazards posed by measurement difficulties and negotiating externalities, governance mechanisms that facilitate exchange take on added importance.

\section{Government Opportunism}

Another source of incompleteness in any resolution to site a NIMBY project rests on the credibility of a political environment to enforce, and not disturb, the agreement. For example, NIMBY opponents might demand assurances from a local government to monitor a sited facility, provide a neighborhood infrastructural or tax relief, or pledge to a future development plan that would benefit the affected areas. Political leaders are quite likely to make such commitments, but how can NIMBY opponents know government officials will keep those promises? Indeed, how can they know those promises will be kept by the officials' successors?

NIMBY opponents cannot demand assurances from government officials like those they can demand by contract from developers and other private entities. One might label this the curse of sovereignty-the essential inability for political leaders to make credible commitments in agreements with private citizens. ${ }^{120}$ The issue of credibility is particularly important regarding promises made by local governments, for local governments are prohibited from entering into binding contracts restricting use of the police power, making credible commitments all but impossible. ${ }^{121}$

Moreover, the government's carte blanche to renege on agreements imbues negotiations between developers and NIMBY opponents with further uncertainty and severely limits a government's ability to assist development projects. This is particularly unfortunate because governmental intervention could be extremely useful in resolving NIMBY disputes. For example, a government could assist negotiations directly by authorizing an agency to take part in development plans or by acting as a guarantor to certain financial considerations. A government might also bestow upon a private developer the power of eminent domain or offer its police powers to the developer's agenda. If any assistance a government gives can be promptly taken away, then government actors are severely limited in their ability to intercede.

120 The credibility of political actors-specifically, the credibility of a government's pledge to refrain from expropriating private investment-is of great interest to scholars studying the political transaction costs of international investment. The seminal work in this area is Levy \& Spiller, supra note 5. See also Witold J. Henisz, The Institutional Environment for Multinational Investment, 16 J.L. ECON. \& ORG. 334 (2000).

121 See OSBORNE M. REYNOLDS, JR., HANDBOOK OF LOCAL GOVERNMENT LAW 675-76 (2d ed. 2001) (citing cases for the proposition that: "[A] local government cannot validly promise a private party that governmental power will not be exercised in a particular way as to that party; such an agreement clearly curtails the legislative or administrative discretion that citizens are entitled to have from their government. . . . It seems that the public policy against any such restrictions on municipal exercise of power is now so firmly established that everyone should be on guard against entering into these contracts and that all relief on these agreements will universally be denied."). 
However, the likelihood of a particular municipality acting arbitrarily, and thus the degree of uncertainty and risk that sovereignty causes, varies across different polities. In some political regimes, power might be more centralized, with fewer veto points or less heterogeneous constituencies. Alternatively, some polities might have procedures or institutions in place that would hinder government actors from engaging in conduct that might disrupt stated development plans. Like legally induced asset specificity, the problem of government opportunism varies not across NIMBY projects themselves, but instead across the locations where NIMBY disputes occur.

In sum, that future government action could unsettle agreements is realistic. When viewed ex ante, it presents a significant contractual hazard that inhibits resolution of NIMBY disputes.

\section{Governance Mechanisms}

States have developed a diverse array of regulations to respond to the NIMBY problem, many addressing both the different elements of the siting process and the siting of different facilities. Consequently, a diverse assortment of regulations is available for review.

Critical to the TCE conception of governance mechanisms is the notion that institutions vary in their attributes, particularly along the dimensions of incentive intensity, administrative controls, and adaptation performance. ${ }^{122}$ Governing institutions can be differentiated along a spectrum ranging from markets (with high incentive intensity, low administrative control, and autonomous adaptation) to hierarchies (with low incentive intensity, high administrative control, and coordinated adaptation). Equally significant, this spectrum includes numerous hybrid governing mechanisms that employ both market and hierarchical elements. As was noted earlier, recent work by Williamson and Dixit has likened regulation to a hybrid mode of governance that lies within the market-hierarchy spectrum. ${ }^{123}$ Moreover, regulations are not restricted to only one organizational form but instead embody a diverse collection of governing relationships.

Consistent with TCE terminology, some scholars have differentiated between assorted regulations according to the degree of institutional intervention they impose, i.e., how comparatively "market" or "hierarchical" they are. These labels can be applied with traditional TCE distinctions: Market regulation exhibits a greater degree of incentive intensity, less administrative control, and more autonomous adaptation as compared to hierarchical

122 See Willlamson, supra note 7 , at 219-75. Transaction cost economics also dimensionalizes governance according to contract law. Each of the regulatory mechanisms discussed here falls under the same contract law regime, neoclassical contract law. Faced with the prospective breakdown of relations, additional governance structures (such as government regulation) are instituted to facilitate gap filling, dispute resolution and adaptation. Id. at 95-100.

123 DIXIT, supra note 93, at 1-36; WILLIAMSON, supra note 7, at 145-70. 
regulation. Such characterizations of regulation, for example, are akin to distinctions drawn between incentive regulation, whereby government intervention could be said to assist the operation of the market, even though market mechanisms remain the primary forces that organize exchange, and command and control regulation, whereby government intervention is more direct and bureaucratic power is the primary force that organizes exchange. ${ }^{124}$ State siting regulations for waste facilities likewise occupy this spectrum of variance, exhibiting both market and hierarchy attributes in varying degrees, and they accordingly range from comparatively market-oriented regulations to comparatively hierarchical regulations. Three broad categories of siting regulation-information-enhancing, process-enhancing, and marketsubstituting - lie along this market-hierarchy spectrum and deserve additional discussion.

\section{Information-Enhancing Regulations}

The purpose of information-enhancing regulations is to mitigate the hazards brought on by information and measurement problems. These regulations are designed to facilitate a complete exchange of information between negotiating parties and to force the disclosure of private information when such information is deemed to have value for the opposing side. They also imbue the exchange of information with greater credibility, since parties are disclosing knowledge to comply with regulatory standards and not for negotiation posturing.

These regulations are comparatively "market" oriented, since they are intended to support or add structure to market interactions. Informationenhancing regulations are designed to fully inform the market players or to alter the incentives these parties face. Such regulations do not dictate how firms or private parties should behave in a given instance, and the relevant exchange is still controlled by the market players themselves. Three important examples of information-enhancing regulations include:

Environmental Impact Statements (EIS), which are designed to increase the availability of information concerning new projects and disclose how a particular project will affect the surrounding natural and physical environment, such as drinking water, air quality, and traffic. These statements are mandated by several federal statutes, including the National Environmental Policy Act of

124 DAVID P. BARON, BUSINESS AND ITS ENVIRONMENT 251 (1993); see also MuRRAY L. WeIdENBAUM, BUSINESS AND GOVERNMENT IN THE GLOBAL MARKETPLACE 20-29 (7th ed. 2003) (introducing theories of regulation and the rationales that "have been put forth to justify this type of govemment intervention in the economy"). 
$1969,{ }^{125}$ and many states have enacted similar statutes that apply to additional projects, including those that involve a state subsidy or permit.

Determination of Need Statements, which require developers to provide a statement detailing why a proposed facility is needed, what alternative sites were considered, ${ }^{127}$ and the justifications for picking a particular site.

Demand and Supply Forecasts, which may be part of a determination of need statement, require that developers forecast the expected demand for a facility's services and how the facility will meet that demand. ${ }^{128}$

Although these information-enhancing regulations serve as vehicles for information exchange, they are also common tools of opposition, serving to delay construction of an undesired facility. ${ }^{129}$ In other words, for some transactions, invocation of these regulations may reflect intractable negotiating hazards instead of efforts to mitigate hazards. For such transactions, information-enhancing regulations may be insufficient to bring about efficient negotiation, and more hierarchical regulations may be required.

\section{Process-Enhancing Regulations}

Process-enhancing regulations are rules that affect the process by which parties to a siting agreement negotiate. Because these regulations generally entail added state involvement in shaping how negotiations take place, they are more hierarchical than information-enhancing regulations. But primary decision-making authority remains in the hands of the developer and the local negotiating parties, so these regulations are nonetheless largely marketoriented. Three prominent examples of this type of regulation are the following:

Formal Declaration of Parties, which create local negotiating committees that represent parties affected by a proposed facility. ${ }^{130}$ The declarations are designed to ensure comprehensive representation of local interests, and they grant legal standing to a representative body authorized to negotiate with a developer. ${ }^{131}$ They can mitigate negotiation externalities by precluding the option of individual negotiations and forcing collective bargaining.

125 Pub. L. No. 91-190, 83 Stat. 852 (1970) (codified as amended at 42 U.S.C. $\$ \S 4321-4370$ (2000)) (requiring any federal action that significantly affects the human environment to be accompanied by an impact statement).

126 In addition to providing information to parties in siting negotiations, EISs have also become tools of opposition. EIS challenges are among the most effective means of delaying the construction of an undesired facility. This view of EISs lends support to the positive political theory view of regulation discussed in Part II.

127 E.g., WASH. ADMIN. CODE 246-235-086(b) (2005); see also U.S. ENVTL. PROT. AGENCY, Hazardous WASTE FacILITY SITING: A CrITICAL PROBleM 7 (1980) (providing three guiding principles for state siting programs, one of which is that "states should execute a technical evaluation of all proposed sites before any single site is selected").

128 E.g., OR. ADMIN. R. 345-021-0010(n)(F) (2005).

129 RABE, supra note 10 , at 154.

130 E.g., 990 MASS. CODE REGS. 8.01 (2005).

131 See id. at 8.06 . 
Public Participation Measures, which are designed to allow broad public involvement (beyond the local negotiating committee) in the siting process. ${ }^{132}$ Specific public participation measures include public hearings, public representatives on siting and oversight boards, and "public counsels," appointed by the state to represent the public in licensing and permitting proceedings.

Negotiation and Arbitration Regulations, which provide added structure to the negotiations between developers and community representatives by specifying the timing of negotiations, penalties for refusing to negotiate in good faith, and specific dispute resolution mechanisms (such as binding arbitration before a state appointed arbitration board).

\section{Market Substituting Regulations}

The most hierarchical category of siting regulations is market substituting regulations. Unlike information- and process-enhancing regulations, they provide the state considerable power to preempt negotiations between developers and the local siting committee or to overturn decisions made at the local level. Regulatory measures in this category essentially substitute state mandates for local decision-making; in TCE terminology, they are characterized more by administrative controls than by incentive intensity. Three important examples of market substituting regulations in this context are:

State Overrides, which provide a state agency with veto authority over decisions made at the local level. ${ }^{133}$ They serve as a powerful counter to negotiations and to political action.

State Preemptive Authority, which permits certain state agencies to preempt local government authority. Such authority permits agency planners to ignore NIMBY opposition and make siting decisions pursuant to state policy alone, regardless of local political preference.

State Inventories and Ownership, which authorize state officials to inventory sites suitable for socially desirable facilities and to complete as much of the review process as possible before a developer expresses interest. The goal is to complete a significant part of the siting process without provoking local opposition, thus protecting a developer from a political fight. In a few states, officials not only review and inventory acceptable locations but also

132 See, e.g., 25 PA. CODE $\S \S 24.1-24.4$ (2005).

133 David Morell \& Christopher Magorian, Siting Hazardous Waste FaCilities: LOCAL OPPOSITION AND THE MYTH OF PREEMPTION 92-97 (1982); O'HARE ET AL., supra note 12, at 57. Exercising these regulations does not necessarily remove the developer's incentive to negotiate with the host community. These regulations certainly raise the developer's reservation option, and consequently may change the content of these negotiations, but developers may still find value in entering into negotiations with community leaders (thus giving concurrent roles to other, less hierarchical regulations). 
purchase the properties. Developers then enter into negotiations with the state in order to purchase the land and begin construction. ${ }^{134}$

To summarize, the hazards inherent in siting solid and hazardous waste facilities have led to the development of a host of regulatory mechanisms. Their primary purpose is to enhance cooperation among all parties affected in building and locating these socially beneficial but locally undesirable facilities. They can be described as fitting within information-enhancing, processenhancing, or market-substituting categories, each of which, under a TCE analysis, fits into a market-hierarchy spectrum: Market-substituting regulations are the most hierarchical, information-enhancing regulations are the most market-oriented, and process-enhancing regulations exhibit intermediate qualities.

\section{Discriminating Alignment}

The fundamental hypothesis of TCE is that "transactions which differ in their attributes [are aligned] with governance structures (which differ in their costs and competencies) in a discriminating (mainly transaction-costeconomizing) way." ${ }^{\prime 35}$ With respect to waste facilities, TCE predicts that siting transactions, whose attributes pose various types and degrees of hazards, should be aligned with regulatory mechanisms that possess the mix of market and hierarchy features that can best remedy these hazards.

The four predominant types of solid and hazardous waste facilities are solid waste landfills, solid waste incinerators, hazardous waste storage and treatment facilities, and hazardous waste disposal facilities. Siting each represents a unique transaction and poses its own hazards to the contractual relationship between the developer and the host community (e.g., the problems and issues that arise in relation to siting a landfill are different from those involved in siting a hazardous waste site). ${ }^{136}$ These hazards, including negotiation externalities, measurement problems, asset specificity, and government opportunism, differ across siting transactions.

We reviewed sources that describe the technical aspects of these various types of facilities, ${ }^{137}$ and we attempt to quantify ${ }^{138}$ each of the individual

134 It is important to point out that the use of state inventories does not imply that the local community is helpless to oppose undesirable facilities. Rather, these measures simply remove an important piece of the siting process from local control. Often overrides and inventories are combined with some form of negotiation between the developer and the local community.

135 WILLIAMSON, supra note 7, at 46-47.

136 See Glenn Blomquist, The Effect of Electric Utility Power Plant Location on Area Property Value, 50 LAND ECON. 97, 100 (1974) (discussing the effect of power plants on property value, using the "rather special instance" of a Chicago plant as the "sole disamenity" in the community).

137 E.g., KIRK-OTHMER ENCYCLOPEDIA OF CHEMICAL TECHNOLOGY, supra note 115; A. Streeter, Pittston-Eastport: An Energy Impacts Evaluation, in NUCLEAR ENERGY FACILITIES AND PUBliC CONFLICT: THREE CASE STUDiES (Judah L. Rose ed., 1979). Notes from a colleague's visits to solid and hazardous waste sites taken between January and March 1995 were also consulted. 
hazards discussed above involved in the siting of each facility. First, siting a facility requires a developer to negotiate with a collective of different parties, so each project will experience negotiating externalities. ${ }^{139}$ Second, some contractual hazards, such as government opportunism, vary more by transactional setting than by individual project, though particularly controversial projects, such as hazardous waste disposal facilities, might be more likely to invite political intervention than other projects. In any event, even after devising regulatory policy to accommodate for differences between waste facilities, the optimal regulatory regime will also depend on the legal and political setting.

Alternative waste facilities exhibit more important variation in the two other hazards discussed above: measurement problems and asset specificity. Solid waste landfills present measurement problems in that they pose threats of odor, seepage into water systems, and other environmental dangers; ${ }^{140}$ but landfills have developed reliable technologies to deal with hazardous materials to substantially reduce risks to human health and the environment. ${ }^{141}$ In addition, those risks that do exist can be assuaged with fairly simple technologies, and the transparency of activities performed at landfills makes monitoring relatively simple. ${ }^{142}$ By contrast, solid waste incinerators pose a greater degree of measurement problems since they produce air pollutants of varying dangers across large geographic regions. But with appropriate technology (which, incidentally, also can be hard to measure), air discharges from these facilities can be monitored; moreover, like landfill deposits, solid waste incinerators deal mostly with non-hazardous materials. The greatest measurement problems are posed by hazardous waste disposal facilities. These dispose of materials that genuinely pose environmental threats and pose those threats through a variety of media-e.g., air, water, and ground - that are hard to monitor and detect. ${ }^{143}$ In addition, long latencies between a facility's actions

138 We should emphasize that these are only preliminary estimates of hazards, are largely comprised of educated inferences from a variety of sources, and that therefore the actual challenges to site the facilities we mention might be quite different. However, our contribution is not dependent on the accuracy of these estimates but instead rests on the overall TCE-motivated methodology. We present a template with which policymakers can tailor regulatory schemes to address individual NIMBY challenges, and while useful application of the template relies on estimating contractual hazards accurately, our estimates are designed chiefly to provide only an illustration of our model.

139 Externalities include a facility's impact on future generations, who (though certainly difficult to organize) may be represented in some capacity by certain government agencies. For example, a state agency might intervene in negotiations between a community and a developer to protect future interests.

140 OfFICE OF TeCh. ASSESSMENT, FaCING AMERICA's Trash: What NeXt FOR MuNICIPAL SOLID WASTE? 284-89 (1989) (describing the assorted environmental and health effects imposed by landfills).

$141 \quad$ Id. at $276-84$.

142 See id.

143 See, e.g., JAMES G. ABERT, RESOURCE RECOVERY GUIDE 431 (1983) (describing an Oceanside, N.Y. plant's wastage problem that extended over several years and the subsequent need to visit similarly-situated European plants for a "satisfactory explanation"). 
(e.g., an accidental spill) and health or environmental outcomes can make the impact of these facilities largely uncertain and difficult to prove.

Asset specificity plays a role in each of these facilities as well. Landfills are generally built to service specific customers in the region and are thus site specific, but their physical asset specificity is relatively low because ultimately they are covered and made into parks or parking lots or are sold for industrial development. Physical asset investments in solid waste incinerators are also typically generic and can, with relatively little difficulty, be redeployed for alternative uses. Hazardous waste storage and treatment facilities contain both physical asset and site specificity, probably similar to that of landfills and incinerators. Finally, hazardous waste disposal facilities contain the greatest asset specificity since rigorous zoning requirements impose severe limitations as to where these may be sited, and hazardous materials preclude them from being employed for an alternative use.

In sum, and as reflected in Table 1, we approximate that landfills have low measurement hazards and moderate asset specificity, solid waste incinerators have moderate measurement hazards and moderate asset specificity, hazardous waste storage and treatment facilities have high measurement problems and moderate asset specificity, and hazardous waste disposal facilities have high measurement problems and high asset specificity.

\section{Table 1}

\begin{tabular}{lcccc}
\hline Type of WEF & $\begin{array}{c}\text { Negotiation } \\
\text { Externalities }\end{array}$ & $\begin{array}{c}\text { Measurement } \\
\text { Problems }\end{array}$ & $\begin{array}{c}\text { Asset } \\
\text { Specificity }\end{array}$ & $\begin{array}{c}\text { Government } \\
\text { Opportunism }\end{array}$ \\
\hline $\begin{array}{l}\text { Solid Waste } \\
\text { Landfills }\end{array}$ & ++ & + & + & + \\
$\begin{array}{l}\text { Solid Waste } \\
\text { Incinerators }\end{array}$ & ++ & ++ & ++ & + \\
Hazardous & & & & \\
$\begin{array}{l}\text { Waste Storage } \\
\& \text { Treatment }\end{array}$ & ++ & ++ & ++ & + \\
$\begin{array}{l}\text { Facilities } \\
\text { Hazardous }\end{array}$ & & & & \\
Waste Disposal & ++ & +++ & +++ & ++ \\
Facilities & & & & \\
\hline
\end{tabular}

Note: $+/+1+++$ denotes the severity that the given hazard poses on the individual waste facility.

Figure 2 then translates the data from Table 1 into TCE-motivated hypotheses. The $\mathrm{X}$-axis reflects a project's asset specificity and the Y-axis 
reflects its measurement problems, so the area from the origin indicates the cumulative contracting hazards created by siting each type of waste facility. ${ }^{144}$ Since the discriminating alignment hypothesis posits that transactions posing greater hazards will require additional governance mechanisms, the diagonal lines representing the alternative regulatory regimes move farther from the origin in accordance with their respective locations along a market-hierarchy spectrum. This TCE model suggests that landfills and solid waste incinerators will require fewer hierarchical regulations than will hazardous waste storage and treatment or disposal facilities in order to achieve efficient outcomes. Figure 2 summarizes these predictions and illustrates how increasing hazards (along either the $\mathrm{X}$ - or $\mathrm{Y}$-axis) should prompt increasingly hierarchical governance mechanisms. ${ }^{145}$

\section{Figure 2: Waste facilities, with their respective hazards, aligned with their optimal regulatory governance}

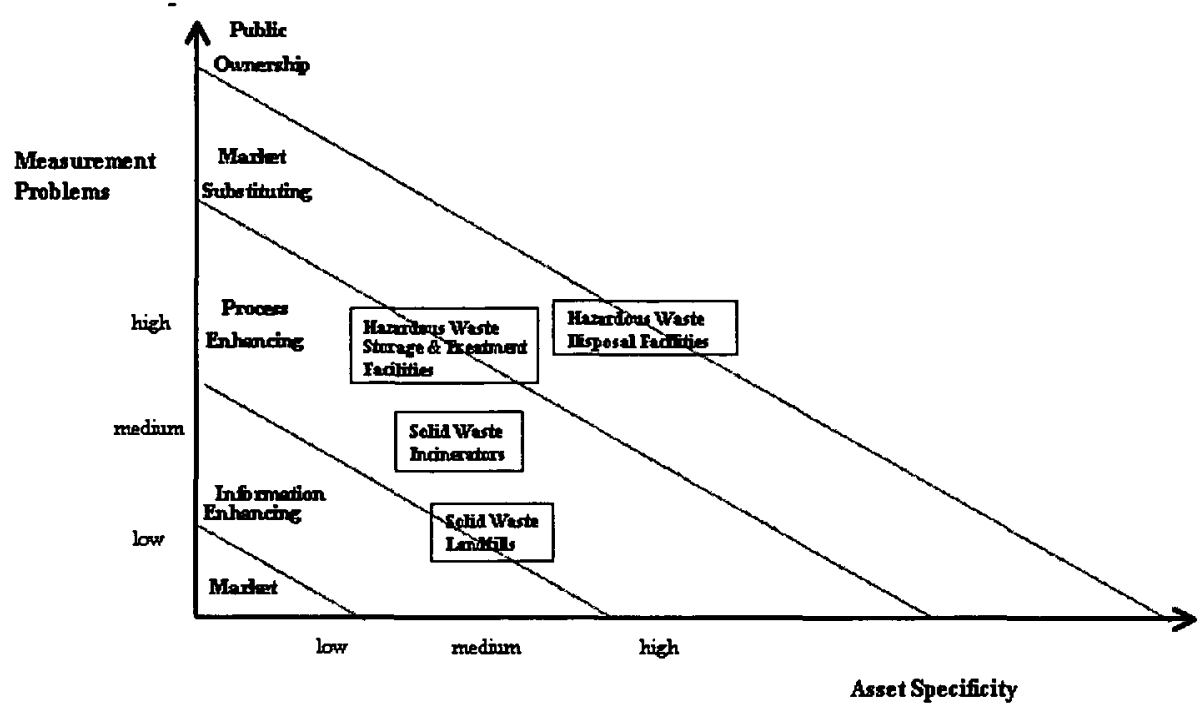

144 Because negotiating extemalities and the threat of political opportunism exist (with relatively little variation) for each type of facility, and because rudimentary graphical illustrations permit the depiction of only two dimensions, these two categories of contracting hazards are excluded from Figure 2.

145 Note that Figure 2 implicitly assumes that the discussed contractual hazards have a certain additive quality to them. In other words, it suggests that finding the optimal regulatory governance device requires determining the cumulative hazards, whatever the source. Consequently, the regulatory regime most appropriate for a project that imposes high measurement costs but low asset specificity would also be most appropriate for a project with low measurement costs and high asset specificity. While we think this additive quality is a likely feature of siting noxious facilities, it by no means is a necessary feature. Consequently, Figure 2 is to be read as a suggestive heuristic through which one can understand when different regulatory devices might be appropriate. Though the most effective approach, as has been stated throughout this paper, is to tailor a specialized regulatory process for each project individually, it is useful to have a generalized understanding of how regulatory regimes can match different projects. 
This comparison of alternative regulatory mechanisms suggests a general approach to devising regulatory policy for siting facilities. According to Figure 2 , the siting processes for landfills and incinerators require informationenhancing and process-enhancing regulations, but additional process-enhancing regulation is undesirable. This suggests that employing preemptive or marketsubstituting regulations for these facilities would constitute overregulation and would generate sub-optimal policy outcomes. While these facilities might still be sited successfully under an overregulated regime, the locations for such facilities and the associated compensation schemes, if any, would be less able to match social preferences than would market-enhancing or similar regulations. Alternatively, siting treatment, storage, and disposal facilities for hazardous waste requires more regulatory support than siting landfills; thus, process enhancing and market substituting regulations are required. Though such a regulatory regime might not solicit neighborhood participation and its associated benefits, failure to provide adequate regulatory support could lead to a failure to site socially desirable facilities altogether.

Certainly, our hypotheses are not limited to two dimensions, and the exercise of aggregating the cumulative hazards associated with a certain transaction can incorporate additional hazards into the analysis. For example, one can imagine Figure 2 in three dimensions (which would appear as a pyramid on its side) that measures three different hazards along axes $\mathrm{X}, \mathrm{Y}$, and $\mathrm{Z}$ and places increasingly hierarchical regulations in the three-dimensional spaces that expand away from the origin. Policy recommendations would then follow, just as it did in Figure 2, from a plotting of the individual waste facilities in the three-dimensional space. The core lesson remains the same: This transaction cost approach produces a concrete template for a flexible regulatory policy. Given the qualities of a certain facility, this approach reveals the preferred regulatory tools to site that facility.

\section{Preliminary Evidence}

This paper's primary purpose is to develop a TCE approach to understanding siting regulations. While a formal empirical test of the predictions developed here is beyond this Article's scope, the selected case studies below illustrate how the regulatory governance mechanisms discussed here can support (or, when either absent or inadequately designed for the nature of the intended transactions, fail to support) the siting of socially desirable facilities. It should be emphasized that our model does not assume ex post efficiency. In other words, some regulations, whether from poor policy making or other limited judgments, are actually inappropriately aligned with the transactions they are intended to govern. Although the difficulties in siting waste facilities have seriously impeded necessary projects for approximately thirty years, few states have experimented with process-enhancing regulations that facilitate siting negotiations, and competitive forces, if any, are insufficient 
to drive optimal regulatory outcomes. This is partly because the political process is not a market with free entry, and feedback mechanisms to address inefficient policies are rarely effective. For this reason, regulatory "misalignments" are presumably endemic in state regulatory regimes and will lead to suboptimal results. Examining both regulatory successes and failures is instructive as to how regulatory devices can govern particular economic activity in a transaction-cost-minimizing way.

\section{A. Three Case Studies}

Relying on case studies inherently restricts the analysis to small sample sizes, which makes it more difficult to support generalizations about the TCE hypothesis. Nonetheless, a careful analysis of specific instances where siting certain waste facilities encountered political opposition can serve some worthwhile purposes. First, such an analysis illuminates the microanalytic dimensions of the siting process and reveals the specific hazards of an individual transaction: what concerns local residents, how concerns translate into political pressures, and how negotiations between conflicting parties progress (or fail to progress). Second, it illustrates the role regulation plays to support the transactions and the consequences that ensue when adequate regulation is absent. And third, an examination of specific disputes in different municipalities introduces variation in both the type of transaction and the nature of the regulatory regime. The three case studies below each present a different pairing of a NIMBY project with a governance mechanism: The first is an effort to site a solid waste incinerator under a regime of only informationenhancing regulations; the second is a landfill project under a regime of information-enhancing and process-enhancing regulations; and the third is a hazardous waste facility being sited under information-enhancing and processenhancing regulations. The success of the second and the failures of the first and third lends support to our recommendations for a flexible regulatory policy that matches siting processes appropriately with individual projects.

\section{Philadelphia 1988}

Throughout the late $1980 \mathrm{~s}$, landfills were being closed across the Northeast, and major urban centers were facing waste disposal crises. ${ }^{146} \mathrm{By}$

146 The late 1980 s and early 1990 s, especially, was a time when the attention of the media and of major policymakers was focused on a mounting municipal solid waste crisis. See NATURAL RES. DEF. COUNCIL, TOO GOOD TO THROW AWAY: RECYCLING'S PROVEN RECORD, ch. 4 (1997), available at http://www.nrdc.org/cities/recycling/recyc/chap4.asp ("In 1986, . . more than two hundred articles appeared in major newspapers and magazines throughout the United States quoting local public works officials throughout the country who found that polluting landfills, rising waste disposal costs, and fights over dangerous waste incinerators were among the two or three greatest public-policy problems they had to deal with."); George J. Church at al., Garbage, Garbage Everywhere, TimE, Sept. 5, 1988, at 81; Peter S. Menell, An Economic Assessment of Market-Based Approaches to Regulating the Municipal 
1988, Philadelphia, perhaps more than any other city, was facing a severe disposal crisis. Disposal costs per ton had nearly tripled since $1983,{ }^{147}$ and low capacity in nearby landfills forced the city to dump much of its solid waste in sites as far away as Columbus, Ohio. ${ }^{148}$ The city frantically searched for new sites. One proposal tried to persuade the city of Houston to accept some of Philadelphia's solid waste, other attempts propositioned sites in Virginia, South Carolina, and Georgia. ${ }^{149}$ Meanwhile, a barge named The Khian Sea carrying 14,000 tons of Philadelphia's waste had been roaming the seas, searching for a dumping site, for nearly two years. ${ }^{150}$

Some cities began to rely increasingly on trash incinerators, which could reduce the volume of solid waste by as much as $90 \% .{ }^{151}$ Philadelphia at the time had two operating trash incinerators, but they operated on outdated technology, were known environmental hazards, and had prompted twenty years of closure demands. ${ }^{152}$ As Mayor W. Wilson Goode began his second term in January 1988, his administration proposed constructing a new "trash-tosteam" facility that would replace the two older incinerators. The proposal was designed to address the waste disposal crisis while bringing better, more environment-friendly technology to trash disposal. Deputy Mayor Marjorie Adler, testifying on April 13, 1988 before the Philadelphia City Council, argued that the new trash incinerator would stabilize the city's long-term trash disposal costs by reducing its dependence on expensive landfills while minimizing the environmental and health costs associated with trash incineration. ${ }^{153}$ In addressing these health concerns, the administration cited a panel of medical experts who determined that the health effect of emissions from the proposed plant would be equal to "one person smoking two cigarettes or drinking two Diet Cokes in a lifetime."

The trash-to-steam proposal would seem to generate an increase in overall surplus, making it potentially Pareto improving. It would have reduced overall incinerator emissions while disposing of more solid waste and reducing expenses on waste disposal. Indeed, one poll showed that most Philadelphians favored the project for the new incinerator, and support was as high as $70 \%$ in

Solid Waste Stream (Boalt Working Papers in Pub. Law, Paper No. 126, 2004). It therefore is no surprise that all three case studies occurred within this time period.

147 Faye Rice, Where Will We Put All That Garbage?, FORTUNE, Apr. 11, 1988, at 96, 96.

148 Houston Fights Proposal To Import Philadelphia Trash, REUTERS, Feb. 3, 1988, LEXISNEXIS Academic Universe.

149 William K. Stevens, Trash Disposal Problem Besieging Philadelphia, N.Y. TimEs, Feb. 20,1988 , at 7 .

150 Karen Tumulty, Trash Disposal Crisis: No Dumping (There's No More Dump), L.A. TIMES, Sept. 2, 1988, at 4 .

$151 \quad$ Id

152 Rice, supra note 147 , at 98.

153 Robin Clark, It Was Familiar Opposition to a Familiar Proposal, PHILA. INQUIRER, Apr. 14,1988 , at B7.

154 Stevens, supra note 149. 
many neighborhoods. ${ }^{155}$ But the siting process devolved into a classic NIMBY political battle as a vocal Trash-to-Steam Alternative Coalition emerged from the South Philadelphia neighborhood near where the proposed facility would be sited. The coalition flexed its political muscle before city council and brought a "foot-stomping, sign-waving" gang of citizens to the Council's hearings. ${ }^{156}$ They mounted what one administration official called "as fierce opposition as anyone could imagine." 157

Because a bond issue was required to raise the necessary capital funds, the project needed City Council approval. Without the involvement of an expedited regulatory siting mechanism, the project had to pass through the open political process. Consequently, as the administration attempted to enter into negotiations with interested parties, local opposition rounded up Council members to block the proposal. One of South Philadelphia's advocates continued to rail against the proposal, threatening "to fight this thing until I'm not here anymore," and other members joined suit. ${ }^{158}$ The opposition expressed itself through adamant neighborhood groups, grandstanding politicians, and public interest representatives. The diversity of interests involved in the opposition created further difficulties for the administration to negotiate a settlement, making coordinated bargaining substantially more difficult, and talks continued fruitlessly into the summer. Mayor Goode eventually resigned to call the plan "dead" on July 27,1988 , and bitterly noted that residents would consequently face higher trash disposal bills. ${ }^{159}$

Why was the administration unable to mobilize its majority support and reach a negotiated settlement with the South Philadelphia residents? Much of the answer lies in the hazards inherent in siting waste incinerators. Jerome Balter, a spokesperson for opponents of the project, "accused administration officials of misrepresenting the plant's safety standards." 160 Other opponents cited many other potentially harmful effects incinerators may cause--airborne dioxins, particulates, and ash-despite the noted improvements in incinerator technology. As one industry expert observed, "it's very clear that the technologies for new plants are a lot better, but it always comes down to a value judgment. Building up public confidence is a very critical factor." ${ }^{161}$ In short, the complexity of the information, or the impacted nature of the information, presented contracting hazards in the negotiations and impeded efficient bargaining. These hazards were further complicated by negotiating

155 Trash: The Boomerang's Back, PHILA. INQUIRER, Apr. 18, 1988, at A14.

156 Clark, supra note 153.

157 Tumulty, supra note 150.

158 Clark, supra note 153.

159 Philadelphia Mayor: Trash-to-Steam Plan Dead, U.P.I., Aug. 27, 1988, LEXIS-NEXIS Academic Universe.

160 Clark, supra note 153.

161 Tumulty, supra note 150; see also RABE, supra note 10, at 107 (attributing successful siting in Greensboro, North Carolina, to "early and extensive public participation"). 
externalities, which impeded coordinated negotiation and any serious attempt to address specific concerns.

The Philadelphia case is one in which a new incinerator was likely to be Pareto improving, but contracting difficulties caused the proposal to fall victim to the political process. Had a more hierarchical governance mechanism supported the siting process, such as that used four years later in Wisconsin, Philadelphia might have been able to address its waste disposal crisis with a new incinerator.

\section{Dane County, Wisconsin, 1992}

Though the Madison, Wisconsin metropolitan area was not experiencing a waste disposal crisis quite like that of Philadelphia, the Wisconsin Department of Natural Resources (DNR) forecasted that municipalities in Dane and surrounding counties "would need new landfill space soon." 162 In response to anticipated rising demand, Browning-Ferris Industries (BFI) proposed to expand its Madison-Prarie landfill from twenty-two to forty-four acres and to accept municipal waste in addition to the industrial waste it then received. ${ }^{163}$

Opposition immediately emerged. Local residents feared traffic congestion, odor, and damage to local enterprise. Further worries came from the nearby Dane County Regional Airport, which feared that the landfill would attract additional birds that would be a threat to planes using their runways. ${ }^{164}$ The most vocal opponent was American Family Insurance (American Family), whose corporate headquarters were 4,700 feet from the planned expansion. American Family sued BFI and organized protests at the Wisconsin State Capitol. $^{165}$

The DNR issued an environmental impact statement nonetheless and declared the proposed expansion to be safe. ${ }^{166}$ Yet this did little to allay opponents' fears. Citizens first argued that the DNR's report was incomplete since it did not consider the "economic and social impact the larger landfill would have on the nearby community." 167 In addition, American Family disputed the results of the DNR study, arguing it overlooked the severity of contamination caused by a nearby landfill that would be exacerbated by the expansion; BFI countered that new technologies in lining landfills would

162 Landfill Expansion Approved; Opponents To Continue Fight, WIS. ST. J., Feb. 8, 1992, at $1 \mathrm{~A}$.

163 Bill Whittaker, American Family Rips Mad-Prairie Plan, CAPITAL TIMES (Madison, Wis.), Mar. 13, 1992, at 3A.

164 Joel Broadway, Landfill Foes Air Worries, WIS. ST. J., Mar. 14, 1992, at 1B.

165 Landfill Foes Will Protest at Capitol, CAPITAL TIMEs (Madison, Wis.), Mar. 12, 1992, at

$3 \mathrm{~A}$.

166 Matt Pommer, DNR Calls Madison Prairie Landfill Safe, CAPITAL TIMES (Madison, Wis.), Feb. 7, 1992, at 3A.

167 Whittaker, supra note 163. 
preclude seepage and consequent contamination of local groundwater. ${ }^{168}$ As opposition grew throughout the spring, the DNR eventually bowed to public pressure and released a second study in June 1992 admitting that the landfill may impose some environmental and economic costs that warrant concern. ${ }^{169}$

By July, little progress had been made. Despite the region's growing need for waste disposal, a vocal opposition had organized and vowed to fight the project. Multiple parties opposed the landfill expansion and mounted individual challenges to block its approval, creating negotiating externalities that would have complicated any effort to enter into bargaining. ${ }^{170}$ Furthermore, environmental impact statements, designed to facilitate the flow of information between BFI and local residents, did little to clarify the landfill's effects and reduce measurement problems. ${ }^{171}$ Multiple hazards seemed to preclude efficient bargaining, and one might have anticipated a stalemate similar to what occurred in Philadelphia.

However, Wisconsin in 1981 instituted new siting procedures, consisting primarily of information- and process-enhancing regulations, aimed to overcome the NIMBY problem. ${ }^{172}$ First, the landfill siting process mandated the establishment of a "local committee" of affected municipalities to represent interested parties. This committee was to be the authorized representative for local interests and the exclusive negotiating partner with the developer. Thus, regulations mandating a local committee precluded opportunities to shirk from negotiations and so minimize negotiating externalities. Second, the landfill siting process administered the negotiations between parties and required them to bargain in good faith or otherwise face binding arbitration or other undesirable consequences. ${ }^{173}$ To facilitate BFI's negotiations with the local committee, the Municipal Waste Siting Board, which supervised the negotiations, scheduled public hearings that resembled a court trial in that parties were subjected to scrutiny by one another and by state environmental officials. The hearing, scheduled for mid-fall and to last several weeks, provided an impetus to all parties involved to enter into rigorous negotiations to reach a settlement. ${ }^{174}$

168 Bill Whittaker, Foes Cite Toxins by Dump, CAPITAL TIMES (Madison, Wis.), Mar. 26, 1992 , at 3A.

169 Mike Ivey, DNR Rethinks Landfill Expansion, CAPITAL TIMES (Madison, Wis.), June 30, 1992, at 3A.

170 Joel Broadway, Trash Handler Alters Landfill Plans, WIS. ST. J., Oct. 13, 1992, at 3D; Mike Ivey, Landfill Firm Rips State About-Face, CAPITAL TIMES (Madison, Wis.), July 2, 1992, at 3A.

171 Ivey, supra note 170; see also Pat Schneider, County Wants Landfill Impact Reviewed, CAPITAL TIMES (Madison, Wis.), July 23, 1992, at 3A.

172 Peter J. Ruud \& Dean M. Werner, Wisconsin's Landfill Negotiation/Arbitration Statute, WISC. BAR BULL., Nov. 1985, at 17, 17.

173 Wisconsin Department of Natural Resources, Wisconsin's Landfill Siting Process, http://www.dnr.state.wi.us/org/aw/wm/solid/landfill/siting.htm (last visited Nov. 8, 2005).

174 Ivey, supra note 170. 
In mid-October of 1992, both BFI and American Family made substantial concessions and pushed negotiations toward fruitful results. ${ }^{175}$ On February 4, 1993, a creative agreement was finalized. BFI would expand the landfill but only to receive additional industrial waste, thereby not accepting the municipal waste that would attract birds that might endanger the local airport. BFI would further pledge to not seek to expand the landfill, to "limit the number of daily truck trips" and the landfill's height, and to "install berms and implement other landscaping to minimize the visual and aesthetic impact of the site." BFI would also establish a 'neighbor to neighbor' group consisting of members from BFI, American Family, and other interested parties to discuss additional concerns of nearby residents. ${ }^{176}$ Thus, the agreement compromised on environmental, economic, and monitoring issues while still alleviating the region's need for solid waste disposal.

In sum, although numerous elements of the siting transaction might have blocked a final agreement, the siting regulatory process mitigated contracting hazards and created a process wherein bargaining led to a final resolution. The Wisconsin regulations are notable in that they employed both market and hierarchical elements. They intervened with information- and processenhancing regulations that directed how parties may proceed, but they allowed the resolution to arrive chiefly through market-oriented negotiations. According to the TCE discriminating alignment hypothesis, this institutional arrangement is comparatively optimal for some transactions-like landfills-in which contracting hazards are moderate, but it may not be effective in supporting transactions with greater hazards, as the Massachusetts case illustrates below.

\section{Massachusetts 1990}

In 1980, Massachusetts passed regulations ${ }^{177}$ that instituted a siting process similar to Wisconsin's, implementing information- and processenhancing regulations designed to force negotiated settlements between developers and local committees. The Massachusetts law, however, extended to siting hazardous waste facilities in addition to landfills and consequently exhibited very little success. In the first twelve years after the law came into force, five proposals for hazardous waste facilities were offered and none began construction.

Examining the Clean Harbors proposal and its aftermath can illuminate how the negotiation-based siting process failed in Massachusetts. ${ }^{178}$ In May

175 Mike Ivey, Landfill Won't Take Municipal Waste, CAPITAL TIMES (Madison, Wis.), Oct. 12,1992 , at $3 \mathrm{~A}$.

176 Mike Ivey, Madison-Prairie Landfill Deal To Relieve Rodefeld, CAPITAL TIMES (Madison, Wis.), Oct. 13, 1992, at 3A.

177990 MASS. CODE REGS. 1.01 to 16.03 (2005) (implementing the Massachusetts Hazardous Waste Facility Siting Act).

178 See O'Hare \& Sanderson, supra note 35, at 369-70, for the Clean Harbors case study. 
1987, Clean Harbors filed its notice of intent to expand its existing hazardous waste transfer station in a highly industrialized section of Braintree, near Boston. The incinerator would destroy some waste on-site rather than transport it to other facilities as far away as Alabama and Arizona, thus saving significant hauling and disposal costs. In October 1987, in accordance with the siting procedures, the proposal was deemed "feasible and deserving" by the state regulators, and a local committee was formed by nearby municipalities to enter into siting negotiations.

The process continued as planned though the following year, with Clean Harbors completing its initial environmental surveys and satisfying its regulatory obligations. But in September 1989, the local committee decided to withdraw altogether from negotiations with Clean Harbors. So although Clean Harbors continued to receive approval from the state's environmental regulators and advance through the regulatory process, the local committee refused to participate in negotiations and instead remained organized to fight the project in the political arena. Gradually, the state politicians responded to local residents' protests. First, the Secretary of Environmental Affairs required Clean Harbors to submit a supplemental environmental impact statement (here likely used as a delay tactic and not as a device to facilitate information exchange) and later to request permission from additional state agencies. Meanwhile, as the review process slowed during the spring and summer of 1990 , local residents solicited Massachusetts' gubernatorial candidates to oppose the plan. By September, all five did. Later that month, additional dissent came from state agencies, and the state's Site Safety Council, which had twice before approved the proposed facility, ruled that the project was no longer "feasible and deserving" of state support. Clean Harbors then saw it was losing the political battle and decided not to appeal the decision, ending its effort to expand its facility without ever meeting to negotiate with the local committee.

Why did the negotiation-based process work for a landfill in Wisconsin but not for a hazardous waste incinerator in Massachusetts? According to O'Hare \& Sanderson,

[the project failed] because many of the site's neighbors did not believe it could lead to an outcome acceptable to them; partly because the state's political leadership gave neighbors, and the developer, no reason to believe it would protect the siting process or the case for hazardous waste facilities itself from localized attack; and partly because the neighbors simply could not understand the health issues and were at best ill-served by the state agencies concerned with them. 179

This evaluation provides two explanations for the projects failure: First, the process did not ensure a credible commitment to either the developer or the residents that an agreement would be in their interest, or, in other words, there was inadequate governance supporting the transaction. And second, the nature 
of the information was too complex and impacted to make efficient bargaining possible. Siting Wisconsin's landfill may have introduced some measurement hazards and other contracting problems, but siting the hazardous waste facility near Boston created far greater measurement problems and gave rise to greater opposition. The market-oriented regulations broke down because coordinated negotiation could not credibly support a transaction with excessive hazards. This observation is consistent with TCE theory, since transactions laden with such hazards require more hierarchical governance.

The three case studies together offer preliminary evidence and some interesting insights into the TCE approach to siting regulations. Since siting waste facilities involve contracting hazards, some kind of governance mechanism is required to support the transaction. The Philadelphia case study illustrates how an attempt to site an incinerator with only informationenhancing regulations led to failure. Alternatively, Wisconsin's informationand process-enhancing regulation provided sufficient institutional intervention and governance to support negotiations and allowed the project to proceed under primarily market-based processes. This regulatory regime, however, proved to be appropriate for only certain types of transactions. The same regulations failed in Massachusetts when applied to facilitate siting a project that was hampered by greater hazards. According to the TCE discriminating alignment hypothesis, a more hierarchical governance mechanism would be required for hazardous waste facilities.

\section{Conclusion}

The purpose of this paper is to employ transaction cost economics to propose a policy strategy for regulating the siting of solid and hazardous waste facilities. Unlike existing approaches to the NIMBY problem, which either require negotiations over compensation or reject community participation altogether, this paper develops a model for flexible regulatory policies. The model's foundation is a theoretical framework for the underlying sources of the NIMBY problem and the appropriate regulatory solutions. Understanding NIMBY disputes as a contracting problem permits utilizing a TCE framework, which systematically tailors regulatory solutions to the assorted political challenges that arise in siting different noxious facilities. The TCE framework identifies the contracting problems inherent in siting such facilities, evaluates the costs and competencies of various regulatory regimes, and matches the two so as to minimize transaction costs.

The result presents an attractive alternative to current regulatory failures. Forceful regulatory interventions that dictate policy outcomes or require negotiations-to-compensate schemes, despite winning the sympathies of those exasperated with recurring NIMBY impasses, fail to harness the benefits of market incentives and bargaining. Regulatory schemes that allow for community participation, creative problem-solving, and effective negotiation 
can, as the Dane County experience illustrates, generate siting agreements that are far superior to what a developer or state planner would order unilaterally. However, regulatory schemes that rely entirely on compensation systems, such as the Massachusetts system, will sometimes be unable to overcome local resistance to siting socially necessary noxious facilities. In short, this flexible approach would avoid the pitfalls of overregulation while providing the regulatory force necessary to overcome NIMBY opposition. Equally important, such a flexible system redeems the opportunity for community participation to improve siting noxious facilities and thus adds significant value to a potentially intractable problem. Recognizing the limitations of creative compensationbased regulations reveals when those regulations can succeed, which is increasingly necessary in the wake of intense skepticism towards compensation schemes. ${ }^{180}$

Moreover, the benefits of employing this TCE model to regulatory challenges extend beyond the efficient siting of NIMBY projects. This template readily applies to any public policy challenge in which public regulations are in a position to mediate a dispute involving two or more parties. Under the rulemaking provisions of the Administrative Procedure Act (APA), federal agencies are frequently required to enact policy that mediates conflicts between interested parties. ${ }^{181}$ Notable examples include disputes between environmentalists and polluters over emission rates, ${ }^{182}$ between rival broadcasters over frequency allocations, ${ }^{183}$ and between food producers and scientific or consumer groups over safety standards. ${ }^{184}$ Often these same rules govern disputes between private parties and other government agencies. ${ }^{185}$ On their face, these disputes are no different from NIMBY conflicts between communities and developers or planners.

Moreover, modern administrative law has at its disposal a menu of regulatory devices. Much like state regulators that oversee siting noxious facilities, federal agencies are subject to a variety of regulatory procedures that guide them through disputes over rulemaking policy. ${ }^{186}$ Sections 556 and 557 of the APA bind agencies to formal rulemaking proceedings that mandate public hearings, ${ }^{187} \S 553(\mathrm{~b})$ and (c) of the APA provide for informal

180 See Munton, supra note 9, at 16-17 (noting the perception of "fierce critics" that compensation schemes are counterproductive to resolving NIMBY disputes); KAHAN, supra note 20, at 4 ("Indeed, there is evidence that compensation schemes at least sometimes make the NIMBY problem worse").

181 Administrative Procedure Act, ch. 324, 60 Stat. 237 (1946) (codified as amended at 5 U.S.C. $\$ \S 551-559$ (2000)); see also Morrison, supra note 28.

182 See, e.g., Seacoast Anti-Pollution League v. Costle, 572 F.2d 872 (1st Cir. 1978).

183 See, e.g., Nat'l Black Media Coal. v. FCC, 791 F.2d 1016 (2d Cir. 1986).

184 See, e.g., United States v. Nova Scotia Food Prods. Corp., 568 F.2d 240 (2d Cir. 1977).

185 One classic example is disputes between non-profits and the Internal Revenue Service, see, e.g., Am. Med. Ass'n v. United States, 887 F.2d 760 (7th Cir. 1989).

186 See Peter L. Strauss, The Rulemaking Continuum, 41 DUKE L.J. 1463 (1992).

187 5 U.S.C. $\$ \S 556-557(2000)$. 
rulemaking procedures for agencies to implement notice-and-comment rulemaking, ${ }^{188}$ and $\S 552$ permits agencies to disseminate interpretive rules or statements of policy with only minimal procedural requirements. ${ }^{189}$ These assorted rulemaking procedures have been dubbed "more formal rulemaking," "informal rulemaking," and "yet-more-informal rulemaking," respectively, 190 and they fit easily into the market-hierarchy spectrum of regulatory devices developed here for siting regulations. ${ }^{191}$ The lessons from this article suggest that the nature of the underlying dispute should determine which of these alternative regulatory tools are optimal.

Although we leave a complete transaction cost analysis of the APA for future research, and although the same analysis would be applicable to states that have their own Administrative Procedure Acts, ${ }^{192}$ this Article's major contribution is not its specific policy recommendations, but rather, its development of a broadly applicable template to chart regulatory reform. We believe our transaction cost model of regulation can inform any policy dispute in which public entities must mediate between opposing parties, and that the theory of the firm will continue to serve far-reaching academic and policy objectives that are well beyond Coase's original formulation.

188 Id. $\S 553(\mathrm{~b})-(\mathrm{c})$.

189 Id. § 552; see also Pac. Gas \& Elec. Co. v. Fed. Power Comm'n, 506 F.2d 33 (D.C. Cir. 1974).

190 See generally PETER L. STRAUSS, ET AL., GELLHORN AND BYSE'S AdMINISTRATIVE LAW 291-400 (9th ed. 1995).

191 See supra Section III.C.

192 See Rui J.P. de Figueiredo Jr. \& Richard G. Vanden Bergh, The Political Economy of State-Level Administrative Procedure Acts, 47 J.L. \& ECON. 569 (2004) (describing state APAs, the history of their respective enactments, and the conditions inducing their passage). 